\title{
On the political economy of financial reform
}

\author{
Yongfu Huang
}

Discussion Paper No. 06/586

June 2006

Department of Economics

University of Bristol

8 Woodland Road

Bristol BS8 1TN 


\title{
On the political economy of financial reform*
}

\author{
Yongfu Huang ${ }^{\dagger}$ \\ Department of Economics, University of Bristol \\ 8 Woodland Road, Bristol BS8 1TN
}

June 9, 2006

\begin{abstract}
This paper studies what induces governments to undertake reforms aimed at financial development. Its starting point is Abiad and Mody (AER 95(1), 2005). Rather than their ordered logit technique, it uses a within groups approach allowing for error dependence across countries and over time. This paper finds that policy change in a country is negatively rather than positively associated with its liberalization level, while the regional liberalization gap does not appear relevant. On the effects of shocks and crises, it suggests that some of the Abiad and Mody (2005) findings are robust, but others are fragile. Furthermore, it claims that the extent of democracy is important for this analysis, and identifies a negative effect of the extent of democracy on policy reform.

Keywords: Financial liberalization; Financial reform; Political economy; Cross country dependence

JEL Classification: D72, F36, G18

\footnotetext{
*I am very grateful to Jonathan Temple for his valuable supervision, comments and assistance throughout the preparation of this paper. Many thanks to Abdul Abiad and Ashoka Mody for making their dataset and Stata code publicly available. The usual disclaimer applies.

${ }^{\dagger}$ Correspondence: Email: y.huang@bristol.ac.uk; Tel: 0044-117-928 8402; Fax: 0044$117-9288577$
} 


\section{Introduction}

Financial liberalization has been one of the key trends characterizing the post-Bretton Woods era, with decreasing capital controls and an increasing participation of developing countries in international financial markets in recent decades. More broadly, domestic financial development, measured in terms of liquid liabilities or stock market capitalization, has risen dramatically in recent decades. By using Bayesian Model Averaging and Generalto-specific approaches, Huang (2005a) examines the long-run determinants of finanical development. However, what are the factors directly stimulating governments to liberalize the financial sector, aimed at enhancing financial development? Building on the framework of Abiad and Mody (2005), this paper attempts to answer this question, and to provide a more comprehensive view of the political economy of financial reform.

Although financial liberalization has been criticized as increasing the likelihood of financial crises and financial fragility, financial liberalization is widely regarded as promoting the flow of financial resources, thereby reducing capital costs, stimulating investment and fostering financial development and economic growth (McKinnon 1973, Shaw 1973, Demirgüç-Kunt and Detragiache 1998, Summers 2000). In practice, governments in recent decades have been committed to reducing direct intervention in the financial system by easing or removing controls over interest rates, credit allocations and financial transactions domestically and internationally, opening up the banking system for foreign entry, and privatizing commercial banks or non-bank financial intermediaries. What are the main factors inducing governments to take these steps?

Abiad and Mody (2005) introduce a framework that rigorously examines the combined effects on policy change of domestic learning, regional diffusion, shocks, crises, ideology, and economic and political structure. Using an ordered logit technique to estimate their specifications, Abiad and Mody (2005) argue that policy change in a country is positively related to its level of liberalization and any liberalization gap from the regional leader. The pace of reform is found to be affected by shocks or discrete changes such as a balance-of-payment crisis, a banking crisis, a new government's first year 
in office, participation in an IMF program and a decline in US interest rates. However, they find that ideology and political and economic structures have "limited influence" on the likelihood of reform.

The Abiad and Mody (2005) analytical framework is attractive in many respects, but some aspects of their empirical analysis may merit further attention. The ordered logit technique they use is not necessarily natural in this context given the nature of the dependent variable, as the change in the extent of financial liberalization. Moreover, their analysis does not take into account the effects of common trends and the possibility of error dependence across countries and over time, which seems especially relevant when the effects of domestic learning and regional diffusion are studied.

Based on their work, this analysis introduces four innovations. Firstly, rather than using their ordered logit technique, this analysis uses a within groups approach to estimating the models, adapted to allow for cross section error dependence. Second, panel-robust standard errors are reported to account for error dependence over time. Third, it adds the extent of democracy into the Abiad and Mody (2005) framework. The level of democracy is a potentially important variable that reflects the political environment in which new policies are approved or rejected, and policy changes take place. Fourth, in addition to focusing on the original dataset used by Abiad and Mody (2005), it takes up a further investigation based on a larger set of countries, in which the Abiad and Mody financial liberalization index is replaced by the Chinn-Ito index of capital account openness (2005).

The paper produces the following findings. In general it confirms the negative effects of banking crises and high inflation on policy change, as observed by Abiad and Mody (2005). It is also consistent with Abiad and Mody (2005) in suggesting that the effects of new governments in their first year and IMF programs are strong when financial sectors are highly repressed, and become weaker as the level of financial liberalization goes up. However, this paper points to the following three distinct conclusions. First, it shows that some of their findings on the effects of crises and shocks are fragile. Second, it is at odds with Abiad and Mody (2005) on the effects of domestic learning and regional diffusion. It suggests that policy change in a country is negatively rather than positively related to its liberalization level, 
and the liberalization gap from the regional leader appears less relevant than in the Abiad and Mody (2005). Third, this analysis observes a significant effect of the extent of democracy, the new variable added to the Abiad and Mody framework, on policy change. The findings on the negative effects of domestic learning and irrelevance of regional diffusion are supported by a larger sample of countries drawing on the Chinn-Ito index of capital account openness.

The following section provides a brief discussion of the model specifications and econometric methods. Section 3 presents the empirical results, based on the original dataset with the Abiad and Mody measure, and a larger set of countries with the Chinn-Ito measure, separately. Section 4 summarizes the conclusions.

\section{Methodology}

This section starts by briefly describing the models used in Abiad and Mody (2005) to study how financial reform is shaped, followed by a discussion of the econometric methods that will be applied in this paper.

\section{$2.1 \quad$ Model specifications}

Below is the general model structure that captures the effects of domestic learning, regional diffusion, discrete changes, and ideology and structure on policy changes.

$$
\begin{aligned}
\Delta F L_{i t}= & \alpha\left(F L_{i t}^{*}-F L_{i, t-1}\right) \\
& +\beta_{1}\left(R E G \_F L_{i, t-1}-F L_{i, t-1}\right) \\
& +\beta_{2}^{\prime} S H O C K S_{i t} \\
& +\beta_{3}^{\prime} I D E O L O G Y_{i t} \\
& +\beta_{4}^{\prime} S T R U C T U R E_{i t} \\
& +\varepsilon_{i t}
\end{aligned}
$$

The dependent variable, $\Delta F L_{i t}$, is used to measure the policy change, the difference between the level of financial liberalization in next period, 
$F L_{i t}$, and the current level of financial liberalization, $F L_{i, t-1} . F L_{i t}$ ranges between 0 and 1 , with 0 and 1 corresponding to complete financial repression and complete financial liberalization, respectively. $F L_{i t}^{*}$ is the desired level of financial liberalization. The adjustment factor, $\alpha$, measures the degree of status quo bias. A lower value of $\alpha$ is associated with more resistance to reform and a greater bias towards the status quo. The first term on the RHS is therefore used to examine domestic adjustment. The second term captures regional diffusion in which $R E G_{-} F L_{i, t-1}$ is the maximum level of financial liberalization achieved in the region. $S H O C K S_{i t}$ denotes discrete changes including four types of crises, including balance-of-payment crises $\left(B O P_{i t}\right)$, banking crises $\left(B A N K_{i t}\right)$, recessions $\left(R E C E S S I O N_{i t}\right)$ and high inflation periods $\left(H I N F L_{i t}\right)$, and three types of internal or external influences like the incumbent's first year in office (FIRSTYEAR $\left.R_{i t}\right)$, the influence of international financial institutions reflected by a dummy for an IMF program of lending $\left(I M F_{i t}\right)$ and the influence of global factors proxied by the US Treasury Bill rate $\left(U S I N T_{i t}\right)$. IDEOLOGY $Y_{i t}$ reflects political orientation including a dummy for left-wing government $\left(L E F T_{i t}\right)$ and a dummy for right-wing government $\left(R I G H T_{i t}\right)$. STRUCTURE $E_{i t}$ represents structural variables (either economic or political), for example the trade openness measure $\left(O P E N_{i t}\right)$ used in Abiad and Mody (2005).

Overall, the Abiad and Mody framework is appealing, covering almost all possible aspects. However, a political structural variable, the extent of democracy $\left(D E M O_{i t}\right)$, may be relevant to the analysis and is added to their framework. It is the Polity indicator "polity2" in the PolityIV Database (Marshall et al. 2003) and seeks to measure institutional quality based on the freedom of suffrage, operational constraints and balances on executives, and respect for other basic political rights and civil liberties. It is called the "combined polity score", defined as the democracy score minus the autocracy score $^{1}$.

\footnotetext{
${ }^{1}$ The democracy and autocracy scores are derived from six authority characteristics (regulation, competitiveness and openness of executive recruitment; operational independence of chief executive or executive constraints; and regulation and competition of participation). Based on these criteria, each country is assigned a democracy score and an autocracy score ranging from 0 to 10 . The larger is the democracy score, the fairer is the election of executive power, the more open is the political process and the higher the
} 


\subsubsection{Benchmark specification}

The benchmark specification assumes that the desired level of financial liberalisation, $F L_{i t}^{*}$, is the perfect level of financial liberalization and the adjustment factor, $\alpha$, is positively related to the level of financial liberalization to allow for the likelihood of domestic learning. Putting $F L^{*}=1$ and $\alpha=\theta_{1} F L_{i, t-1}\left(\theta_{1}>0\right)$ into Equation (1) above and reparameterizing, we have

$$
\begin{aligned}
\Delta F L_{i t}= & \theta_{1} F L_{i, t-1}\left(1-F L_{i, t-1}\right) \\
& +\theta_{2}\left(R E G_{-} F L_{i, t-1}-F L_{i, t-1}\right) \\
& +\theta_{3}^{\prime} S H O C K S_{i t} \\
& +\theta_{4}^{\prime} \text { IDEOLOGY } Y_{i t} \\
& +\theta_{5}^{\prime} S T R U C T U R E_{i t} \\
& +\varepsilon_{i t}
\end{aligned}
$$

This equation is Equation (4) in Abiad and Mody (2005).

\subsubsection{Alternative specifications}

Relaxing two assumptions used in the benchmark specification, three alternative specifications are considered:

First, rather than assuming the desired level of financial liberalization, $F L_{i t}^{*}$, to be full liberalization, it is natural to adopt country-specific measures of the desired extent of liberalization. When plugging $F L^{*}=c(0<c<1)$ and $\alpha=\theta_{1} F L_{i, t-1}$ into Equation (1) above, redefining the coefficients yields the following equation as in Equation (5) of Abiad and Mody $(2005)^{2}$ :

extent of the constraints on executive power. On the contrary, a larger autocracy score reflects a less open political process in a country in terms of less competitiveness and fairness in elections, narrower participation and fewer constraints on the executive.

${ }^{2}$ Here $\theta_{1} c$ and $-\theta_{1}$ are renamed as $\theta_{1}$ and $\theta_{2}$ respectively. $\beta_{1}, \beta_{2}^{\prime}, \beta_{3}^{\prime}$ and $\beta_{4}^{\prime}$ are reparameterized as $\theta_{3}, \theta_{4}^{\prime}, \theta_{5}^{\prime}$ and $\theta_{6}^{\prime}$ respectively. 


$$
\begin{aligned}
\Delta F L_{i t}= & \theta_{1} F L_{i, t-1}+\theta_{2} F L_{i, t-1}^{2} \\
& +\theta_{3}\left(R E G \_F L_{i, t-1}-F L_{i, t-1}\right) \\
& +\theta_{4}^{\prime} S H O C K S_{i t} \\
& +\theta_{5}^{\prime} \text { IDEOLOGY } Y_{i t} \\
& +\theta_{6}^{\prime} S T R U C T U R E_{i t} \\
& +\varepsilon_{i t}
\end{aligned}
$$

Second, the desired level of financial liberalization, $F L_{i t}^{*}$, might be reasonably regarded to be increasing in the level of income. When $F L^{*}=$ $a+b Y_{i t}$ and $\alpha=\theta_{1} F L_{i, t-1}$ are considered, Equation (1) above can be rearranged and reparameterized as Equation (6) in Abiad and Mody $(2005)^{3}$ :

$$
\begin{aligned}
\Delta F L_{i t}= & \theta_{1} F L_{i, t-1}+\theta_{2} F L_{i, t-1}^{2} \\
& +\theta_{3}\left(F L_{i, t-1} \cdot Y_{i t}\right) \\
& +\theta_{4}\left(R E G_{-} F L_{i, t-1}-F L_{i, t-1}\right) \\
& +\theta_{5}^{\prime} S H O C K S_{i t} \\
& +\theta_{6}^{\prime} \text { IDEOLOGY } Y_{i t} \\
& +\theta_{7}^{\prime} S T R U C T U R E_{i t} \\
& +\varepsilon_{i t}
\end{aligned}
$$

Finally, when the possibility that shocks, ideology and structure variables may exert effects on the status quo bias is taken into account, the previous assumption $\alpha=\theta_{1} F L_{i, t-1}$ is replaced by the following equation:

\footnotetext{
${ }^{3}$ Here $\theta_{1} c,-\theta_{1}$ and $b \theta_{1}$ are renamed as $\theta_{1}, \theta_{2}$ and $\theta_{3}$ respectively. $\beta_{1}, \beta_{2}^{\prime}, \beta_{3}^{\prime}$ and $\beta_{4}^{\prime}$ are reparameterized as $\theta_{4}, \theta_{5}^{\prime}, \theta_{6}^{\prime}$ and $\theta_{7}^{\prime}$ accordingly.
} 


$$
\begin{aligned}
\alpha= & \gamma_{1} F L_{i, t-1} \\
& +\gamma_{2}\left(R E G_{-} F L_{i, t-1}-F L_{i, t-1}\right) \\
& +\gamma_{3}^{\prime} S H O C K S_{i t} \\
& +\gamma_{4}^{\prime} I D E O L O G Y_{i t} \\
& +\gamma_{5}^{\prime} S T R U C T U R E_{i t}
\end{aligned}
$$

Putting this expression as well as $F L^{*}=c$ into Equation (1) and redefining the coefficients yields the third specification, Equation (8) in Abiad and Mody (2005), below:

$$
\begin{aligned}
\Delta F L_{i t}= & \theta_{1} F L_{i, t-1}+\theta_{2} F L_{i, t-1}^{2} \\
& +\theta_{3}\left(R E G_{-} F L_{i, t-1}-F L_{i, t-1}\right) \\
& +\theta_{4}\left(R E G_{-} F L_{i, t-1}-F L_{i, t-1}\right) . F L_{i, t-1} \\
& +\theta_{5}^{\prime} S H O C K S_{i t}+\theta_{6}^{\prime} S H O C K S_{i t} . F L_{i, t-1} \\
& +\theta_{7}^{\prime} I D E O L O G Y_{i t}+\theta_{8}^{\prime} I D E O L O G Y_{i t} . F L_{i, t-1} \\
& +\theta_{9}^{\prime} S T R U C T U R E_{i t}+\theta_{10}^{\prime} S T R U C T U R E_{i t} . F L_{i, t-1} \\
& +\varepsilon_{i t}
\end{aligned}
$$

\subsection{Econometric methods}

Abiad and Mody (2005) use an ordered logit technique to estimate the benchmark specification and three alternative specifications with results presented in Tables 7, 8 and 9 of their paper, respectively. A minor problem has been detected in their empirical results in which Singapore is misclassified as an African country while South Africa is misclassified as an East Asian country. The corrected results are presented in Appendix Table 4. In general, the pattern of Appendix Table 4A is similar to that of their Table 7. Appendix Table 4B presents more evidence for $I M F_{i t}$ and $R E G_{-} F L_{i, t-1}-F L_{i, t-1}{ }^{4}$.

\footnotetext{
${ }^{4}$ More specifically, $I M F_{i t}$ has been found to be significant when country fixed effects are excluded, while $R E G_{-} F L_{i, t-1}-F L_{i, t-1}$ appears to be significant no matter whether the country fixed effects are included.
} 
It is worth noting that Appendix Table $4 \mathrm{C}$ shows that $F L_{i, t-1}, O P E N_{i t}$ and $O P E N_{i t} \times F L_{i, t-1}$ appear to be insignificant when country fixed effects are included, different from the Table 9 of Abiad and Mody (2005), which shows these variables to be significant when country fixed effects are included.

More importantly, the analyses conducted by Abiad and Mody (2005) may be questioned in the following two aspects:

The first is that the ordered logit technique they apply may not be natural for this context, although the discrete and ordinal nature of the finanical liberalization level, $F L_{i, t}$, and policy change, $\Delta F L_{i, t}$, may render the ordered logit method an appropriate choice at first glance. Since the dependent variable is not the level of finanical liberalization, but policy change, financial liberalization moving from score 1 to 3 in terms of their original measure $^{5}$ is treated the same as moving from score 16 to 18 for example. However, given the ordinal feature of their original measure, in reality policy change reflected by moving from score 1 to 3, which could be at rather low levels, doesn't necessarily lead to the same extent of financial liberalization as moving from score 16 to score 18, which could be at much higher levels of financial liberalization. Given this particular nature of the dependent variable, resorting to the ordered logit technique may not lead to the expected gains.

Second, like most cross country research, Abiad and Mody (2005) do not take into account the effects of common trends and the possibility of error dependence across countries and over time. This seems especially relevant when the effects of domestic learning and regional diffusion are investigated. The assumption on the error term they use implies that the disturbances are uncorrelated between groups and over time. However, if the error term contains one or more unobserved factors which have the same (or different) effects on every unit, as noted by Phillips and Sul (2003) among others, "the consequences of ignoring cross section dependence can be serious". On the other hand, the consequences of ignoring serial correlation and heteroskedasticity can also be serious, since this may lead to a downward bias in standard errors, and therefore higher significance levels attached to the coefficients. In

\footnotetext{
${ }^{5}$ Divided by 18 , the original measure has been rescaled to get an index, $F L_{i, t}$, ranging between 0 and 1 .
} 
examining the origins of financial openness, Quinn and Inclan (1997) argue that it is critical to consider a common trend, such as changes in consumer tastes and technology, that may exert substantial effects on government liberalization policies as "fundamental but unobservable forces".

The particular nature of the dependent variable and the possibility of error dependence suggest that another estimation approach would be worthwhile. The wide range of the original financial liberalization index from score 1 to 18 and the policy change, $\Delta F L_{i, t}$, from -1 to 1 (after transformation) makes a simpler linear regression method a possible choice for this context. This paper's approach centers on the Pesaran (2006a) common correlated effect pooled (CCEP) estimator, a generalization of the fixed effects estimator that allows for the possibility of cross section correlation. To adjust for serial correlation in individual errors ${ }^{6}$, the panel-robust standard errors due to Arellano (1987) are computed for the CCEP estimates, allowing the errors not only to be serially correlated for a given country, but also to have variances and covariances that vary across countries.

Pesaran (2006a) proposes two common correlated effect (CCE) approaches for large heterogeneous panels whose error contains unobserved common factors. More specifically, this approach augments the one-way fixed effects model with the (weighted) cross sectional means of the dependent variable and the individual specific regressors, analogous to a two-way fixed effects model. Including the (weighted) cross sectional averages of the dependent variable and individual specific regressors is suggested by Pesaran (2006a, 2006b) as an effective way to filter out the impacts of common factors, which could be common technological shocks or macroeconomic shocks, causing between group error dependence.

The Pesaran (2006a, 2006b) approach exhibits considerable advantages. It allows unobserved common factors to be possibly correlated with exogenous regressors and exert differential impacts on individual units. It permits unit root processes amongst the observed and unobserved common effects. The proposed estimator is still consistent, although it is no longer efficient,

\footnotetext{
${ }^{6}$ Although serial correlation in the errors can be alleviated once country fixed effects are included, it may not be fully removed. The standard robust standard errors do not allow for serial correlation in errors, but only for heteroskedasticity.
} 
when the idiosyncratic components are not serially uncorrelated.

In this context, the cross section means ${ }^{7}$ of $\Delta F L_{i t}, G D P_{i, t}$ and $O P E N_{i, t}$ are considered since these variables, continuous variables (not dummy variables), are more inclined to pick up the common effects. To allow the effects to be heterogeneous across countries, the models are augmented with the interactions between country dummies and means of the above variables as well as time dummies. The CCEP estimator has been shown to be asymptotically unbiased and consistent as $\mathrm{N}->\infty$ for both $\mathrm{T}$ fixed or $\mathrm{T}->\infty$, and to have generally satisfactory finite sample properties.

Appendix Table 3 presents the time series properties for three continuous variables, the financial liberalization index $\left(F L_{i, t}\right)$, GDP per capita in PPP terms $\left(G D P_{i, t}\right)$ and trade openness $\left(O P E N_{i, t}\right)$. It contrasts a panel unit root test proposed by Pesaran (2006b) in the presence of cross section dependence with the Maddala and $\mathrm{Wu}$ (1999) Fisher test, which is associated with the assumption of cross section indenpendence of the error term and does not require a balanced panel. Pesaran (2006b) approach augments the standard ADF regression with cross section averages of lagged levels and first-differences of individual series, to control for cross section dependence, the Maddala and $\mathrm{Wu}(1999)$ Fisher test is then applied to this more general setting. With cross sectionally independent errors, and the Maddala and $\mathrm{Wu}$ (1999) Fisher test cannot reject the null of nonstationarity for $F L_{i, t}$, $G D P_{i, t}$ and $O P E N_{i, t}$ when we do not allow for a trend. With a trend, the series of $G D P_{i, t}$ and $O P E N_{i, t}$ are close to being found as stationary. When we allow for a trend, Pesaran's test shows that we can reject the null of nonstationarity for $F L_{i, t}, G D P_{i, t}$ and $O P E N_{i, t}$ at significance level close to $10 \%{ }^{8}$, suggesting that $F L_{i, t}, G D P_{i, t}$ and $O P E N_{i, t}$ may not be $\mathrm{I}(1)$ variables. However, this result should be interpreted with caution since there are reservations as to the power and reliability of these tests.

\footnotetext{
${ }^{7}$ In principal the weights used do not affect the asymptotic distribution of the estimators. The equal weights are used here as suggested for the CCEP estimator (Pesaran, 2006a).

${ }^{8}$ The test statistic takes the form of $-2 \sum_{i=1}^{N} \ln \left(p_{i T}\right)$ in which $p_{i T}$ is the p-value corresponding to the unit root test of the $i^{\text {th }}$ individual cross section unit for the cross sectionally augmented DF regression. The critical values for the Fisher P-test on a cross sectionally augmented regression (Pesaran, 2006b) are provided by M. Hashem Pesaran.
} 
This analysis also employs a normal within groups (WG) approach to estimating the one-way fixed effects models (country fixed effects included), as estimated by Abiad and Mody (2005), with nonrobust standard errors so that how important controlling for error dependence across countries and over time is for this context can be examined by comparing the WG estimates and CCEP estimates. The consistency of the one-way WG estimator for the dynamic homogeneous model is justified by the length of the time series ${ }^{9}$, but this estimator is biased in small samples because of the lagged dependent variable bias. The country fixed effects can be eliminated by an idempotent (covariance) transformation matrix as in within groups estimation.

\section{Empirical evidence}

By applying a within groups approach to the Abiad and Mody (2005) framework with the addition of the extent of democracy, this section presents empirical evidence on what shapes financial reform in two steps, an analysis on the original dataset with the Abiad and Mody (2005) measure in Section 3.1 and an analysis on a larger dataset with the Chinn-Ito (2005) measure in Section 3.2. In each step, the normal one-way fixed effects WG estimates with nonrobust standard errors are contrasted with Pesaran (2006a) CCEP estimates with panel-robust standard errors, with the former assuming that the errors are serially uncorrelated and independent across countries, while the latter allowing for error dependence both across countries and over time.

\subsection{Analysis on the original dataset}

This section concerns the analyses on the benchmark specification (Equation 2) and three alternative specifications (Equations 3,4 and 5) using Abiad and Mody (2005)'s original dataset. The results are presented in Table 1A/B, Table 2, and Table 3 corresponding to Table 7, Table 8 and Table 9 in Abiad and Mody (2005), respectively.

Table $1 \mathrm{~A}$ and $1 \mathrm{~B}$ report the WG estimates and CCEP estimates of the benchmark specification (Equation 2). Table 1A strictly follows the model

\footnotetext{
${ }^{9}$ Since the lagged dependent variable bias arising from the within group transformation can be alleviated when $\mathrm{T}$ is large, for fixed N (Nickell, 1981).
} 
structure of Abiad and Mody (2005) ${ }^{10}$ while Table $1 \mathrm{~B}$ reports $F L_{i, t-1}$ and $F L_{i, t-1}^{2}$ separately, presenting a direct link between policy change, $\Delta F L_{i t}$, and the level of liberalization, $F L_{i, t-1}$. In comparison to the ordered logit estimates in columns 4-6 (with country fixed effects) of Appendix Table 4A, the WG estimates in Table 1A (country effects are included by definition) not only confirm their findings, but also show that FIRSTYEAR $R_{i t}$ and $O P E N_{i t}$ have positive effects on policy change.

Table 1B contains richer information for $F L_{i, t-1}$. However, the WG estimates suggest a positive effect of $F L_{i, t-1}$, possibly leading to instability of the regression models ${ }^{11}$. This is perhaps related to the small sample bias of the one-way within groups estimator, calling for further investigation into a larger group of countries. The CCEP estimates reported in the columns 4-6 of Table 1B have a much larger $\mathrm{R}^{2}$ than the WG estimates. With satisfactory finite sample properties, the CCEP estimates in Table 1B show that policy change is negatively rather than positively associated with the level of financial liberalization, $F L_{i, t-1}$. The effect of the regional liberalization gap, $R E G_{-} F L_{i, t-1}-F L_{i, t-1}$, has been found to be insignificant when more factors are allowed. The CCEP estimates also predict negative effects on policy change of crisis, $B A N K_{i t}$ and $H I N F L_{i t}$. However, the CCEP estimates indicate that the Abiad and Mody (2005) findings on the effects of $B O P_{i t}, I M F_{i t}$ and $U S I N T_{i t}$ are fragile.

Table 2 presents the within groups estimates, WG and CCEP, of the alternative specifications (Equation (3) and Equation (4)) corresponding to Table 8 in Abiad and Mody (2005). The positive signs of $F L_{i, t-1}$ in columns 1-2 continue to suggest the posibility of unstable models. The CCEP estimates confirm the previous observations of Table $1 \mathrm{~B}$ in terms of the negative effects of the level of liberalization, banking crisis, and high inflation. The regional liberalization gap appears to be irrelevant once error dependenece is introduced. Surpringly, the CCEP estimates find evidence for a negative effect of $D E M O_{i t}$ on policy change ${ }^{12}$, implying that the extent

\footnotetext{
${ }^{10} F L_{i, t-1}\left(1-F L_{i, t-1}\right)$ is reported here.

${ }^{11}$ Since the derivative of $\Delta F L_{i t}$ with respect to $F L_{i, t-1}$ is likely to be positive, given the range of $F L_{i, t-1}$ from 0 to 1 .

${ }^{12} \mathrm{DEMO} \mathrm{O}_{i t}$ appears to negatively associated with policy change with weak significance in Table 1B.
} 
of democracy is likely to set reform back.

Next proceed to Table 3 which presents the within groups estimates of the most general specification (Equation (5)). Note that Appendix Table 4C, the corrected version of Table 9 in Abiad and Mody (2005), shows that $F L_{i, t-1}, O P E N_{i t}$ and $O P E N_{i t} \times F L_{i, t-1}$ are insignificant in the presence of country fixed effects. Similar to column 2 of Appendix Table 4C, the CCEP estimates of Table 3 find less evidence for $F L_{i, t-1}$ and $R E G \_F L_{i, t-1}-$ $F L_{i, t-1}$. The coefficient on $R E G_{-} F L_{i, t-1}-F L_{i, t-1}$ is positive, but the coefficient on the interaction term is negative. This seems to be a more plausible pattern, suggesting that the regional liberalization gap has a positive effect on reform when the level of liberalization is low but this effect declines as the extent of liberalization increases. It provides further strong evidence for $D E M O_{i t}$ and its interaction term with $F L_{i, t-1}$, indicating that the extent of democracy tends to hinder the pace of reform ${ }^{13}$. The positive effects of FIRSTYEAR it and $I M F_{i t}$, and negative effects of their interaction terms with $F L_{i, t-1}$ are observed, highlighting that shocks in the form of new governments in their first year and the IMF programs are likely to trigger reform, especially when the extent of financial liberalization is still at its early stage.

The discrepancy between WG estimates and CCEP estimates in the above study has pointed to the fundamental significance of relaxing assumptions on the error term. One may wonder which is more important, controlling for serial correlation in the errors or adjusting for cross section error dependence? To what extent does each relaxation make the results different from those associated with error independence? Answers may be found from Appendix Table 5 which reports the WG estimates with panelrobust standard errors, controlling for serial correlation of errors only, and the CCEP estimates with nonrobust standard errors, controlling for cross section error dependence only. As it stands, both are important. Nevertheless, the quantitatively larger effects (coefficients) and much larger $R^{2}$

\footnotetext{
${ }^{13}$ The coefficient on $D E M O_{i t}$ is significantly negative, and although the coefficient on the interaction term is significantly positive, the range of $F L_{i, t-1}$ from 0 to 1 determines the derivative of $\Delta F L_{i t}$ with respect to $D E M O_{i t},-0.115+0.007 \times F L_{i, t-1}$, is always negative.
} 
associated with the CCEP estimates than with the WG estimates may reflect that controlling for cross country correlation is an especially crucial step for this context. One may notice from Appendix Table 5 that, suggested by either the WG estimates or CCEP estimates, the ideology and economic and political structure in general appear to have a substantial influence on policy change, especially for $L E F T_{i t}$ and $O P E N_{i t}$. This has raised a methodological concern that insufficient consideration of error dependence could lead to misleading findings.

In sum, the above analyses based on the augmented specifications in which $D E M O_{i t}$ is included, allowing for the possibility of error dependence across countries and over time, produce interesting findings. On the one hand, this paper confirms the significant effects of crises and shocks on policy reform identified by Abiad and Mody (2005). More specifically, it confirms negative effects of banking crises and high inflation, and does agree with Abiad and Mody (2005) that a new government in its first year and the IMF program have a strong effect when financial sectors are highly repressed and a weaker effect thereafter. On the other hand, it differs from Abiad and Mody (2005) in the following three aspects. First, it shows that the significant effects of balance-of-payment crises and US interest rates found by Abiad and Mody (2005) are fragile. The second aspect is that it yields opposite findings to Abiad and Mody (2005) on the effects of domestic learning. It shows that the extent of policy reform is negatively rather than positively affected by the existing liberalization level, while the regional liberalization gap does not appear relevant. Thirdly, it addresses the importance of the extent of democracy for the process of financial reform and identifies a negative effect of the extent of democracy on policy change.

\subsection{Analysis on a larger dataset}

This section makes an effort to explore if the findings are robust to a larger set of countries. It makes use of the Chinn-Ito index of financial openness (2005) which is available for 108 countries over 1970-2000. But the ChinnIto index only measures a country's degree of capital account openness, one aspect of six policy dimensions on which the creation of the Abiad and Mody 
measure (2005) is based. Moreover, the country coverage in this analysis is confined to the data availability of crisis variables taken from Bordo et al. (2000) which only contains 55 countries. Since most of the added countries are OECD countries (listed in the Appendix Table 2), the effects of factors like balance-of-payment crises, banking crises, IMF programs and democracy lecel are expected to be weaker ${ }^{14}$. A variable description is presented in Appendix Table 1.

Table $4 \mathrm{~A}$, Table $4 \mathrm{~B}$ and Table $4 \mathrm{C}$ report the within groups estimates corresponding to Table 1B, Table 2 and Table 3, respectively. As expected, these tables show weaker evidence for the effects of shocks, crises, ideology, and economic and political structures on policy reform, except for US interest rates and high inflation. But, since the above analysis in general obtains findings consistent with Abiad and Mody (2005) on the effects of crises and shocks, more emphasis is placed on the robustness of the new findings regarding the negative effects of domestic learning and regional diffusion.

With a larger sample size, both the WG estimates and CCEP estimates in these tables clearly indicate that policy reform is negatively linked to the level of liberalization, $F L_{i, t-1}$, at the $1 \%$ significance level. The tables further confirm that the effect of $R E G_{-} F L_{i, t-1}-F L_{i, t-1}$ on policy change is ambiguous. Removing the variable $I M F_{i, t}$ doesn't alter the pattern of the results, as reported in Appendix Table 6.

Hence, the findings summarized earlier on the negative effects of domestic learning and irrelevance of regional diffusion are largely supported by a larger sample of countries based on the Chinn-Ito index of capital account openness.

\section{Discussions}

The above findings have rich implications. The negative link between policy change and the liberalization level suggests a convergence in the extent of financial liberalization in the sense that countries with highly repressed

\footnotetext{
${ }^{14}$ The panel is unbalanced mainly because data on IMF programs are missing for the following six countries over period 1973-83: China, Costa Rica, Ecuador, Jamaica, Nigeria, Portugal and Uruguay.
} 
financial sectors have more potential to embark on reform, while countries with a highly liberalized financial sector have greater status quo bias - the reform likelihood is "saturated" (Abiad and Mody, 2005). Vivid examples can be easily picked up from the financial liberalization process in East Asia in recent decades. Since 1970s, countries or areas with levels of liberalization much lower than those of the main developed countries (US or UK for example) like Korea, Singapore, Hong Kong, Thailand and China have liberalized their financial system actively and progressively.

This research finds that the significant effect of a regional liberalization gap on policy changes is hard to identify, although two opposite views have been proposed in the literature. Abiad and Mody (2005) suggest that countries with a level of liberalization far from that of the regional leader are found to be more likely to undertake reform, perhaps due to competitive pressure. The larger the gap in terms of liberalization levels within a region, the fiercer the competition among these countries for international capital and technologies. On the contrary, Axelrod (1997) documents that the more similar a country is to its neighbouring nations in terms of economic, social and political developments, the more likely it "adopts one of the neighbour's traits" while Simmons and Elkins (2004) predict that "governments' liberalization policies will be influenced by the policies of their most important foreign economic competitors". This line of research in general predicts that a greater gap from the regional leader tends to be associated with less incentive to compete and less chance to catch up with the regional leader in the short-run, therefore a status quo bias is maintained.

In accordance with Abiad and Mody (2005), the pattern suggested by Table 3, the coefficient on $R E G_{-} F L_{i, t-1}-F L_{i, t-1}$ is positive and the coefficient on the interaction term is negative although insignificant, seems to be in line with the covergence story identified earlier in the sense that countries with lower levels of liberalization relative to that of the regional leader are more inclined to initiate reform, while the reform momentum fades as the liberalization gap from regional leader shrinks. It implies that a greater gap from the regional leader tends to be associated with more incentives to engage in reform.

The finding concerning the negative effect of the extent of democracy on 
policy change is consistent with Fernandez and Rodrik (1991), who argue that there is uncertainty with respect to the distribution of benefits and costs from reform. They contrast democratic societies in which the majority would vote against the reform due to the presence of this uncertainty, just for safety, with authoritarian societies like Taiwan and South Korea (early 1960's) Chile (1970's), and Turkey (1980's) where "reform was imposed by the authoritarian regimes and against the wishes of business." The status quo appears to be more easily dislodged in autocratic societies than in democratic societies.

This finding tends to suggest that ideology and political structure can have a substantial influence on policy change, contrary to some extent to Abiad and Mody (2005), who claim that ideology and economic and political structure have a limited influence on policy change. Although the extent of democracy may exert negative effects in inducing governments to undertake financial reform, democratization is positively associated with changes in financial development as shown in Huang (2005b).

\section{Conclusion}

This paper studies the forces that stimulate governments to undertake reforms to enhance financial development, based on Abiad and Mody (2005). Given the particular nature of the dependent variable, it suggests replacing the ordered logit technique used by Abiad and Mody (2005) with a within groups approach, estimating augmented specifications in which the extent of democracy is added to the Abiad and Mody (2005) framework. To reflect the comovement of economic variables in reality driven by unobserved common factors, this analysis allows for the possibility of error dependence across countries and over time, which seems of especial importance when studying the effects of domestic learning and regional diffusion in the process of financial liberalization. Based on these innovations, the analysis shows that some of the Abiad and Mody (2005) findings are not robust to error dependence and the estimation method. The analysis stresses the importance of carefully taking into account the error structure in the econometric analysis of panel data. It has produced the following significant findings, shedding 
new light on the political economy of financial reform.

First, the paper is at odds with Abiad and Mody (2005) on the effects of domestic learning and regional diffusion. It suggests that policy reform in a country is negatively rather than positively affected by its level of liberalization, and the liberalization gap from the regional leader is less relevant. Countries where financial sectors are relatively repressed may be those having the strongest incentives for reform, and the desire to reform decreases as the level of financial liberalization rises. The regional liberalization gap doesn't seem to have a substantial effect on the likelihood of a country to embark on reform, a possibility discussed in Axelrod (1997), Simmons and Elkins (2004) and Abiad and Mody (2005).

Second, on the effects of shocks and crises on policy reform, this analysis supports some of the findings identified by Abiad and Mody (2005), but finds others to be fragile. More specifically, it confirms the negative effects of banking crises and high inflation. It also agrees with Abiad and Mody (2005) that new governments in their first year and IMF programs have a strong effect when financial sectors are highly repressed and a weaker effect thereafter. But it finds no evidence in support of the effects of balance-ofpayment crises and US interest rates on policy change.

Third, this analysis claims that the extent of democracy is also important for policy change and should be included in the empirical models. The finding suggests a negative effect of the extent of democracy on financial reform.

\section{References}

[1] Abiad, Abdul and Mody, Ashoka. "Financial Reform: What Shakes It? What Shapes It?" American Economic Review, 2005, 95, pp. $66-88$.

[2] Arellano, Manuel. "Computing Robust Standard Errors for WithinGroup Estimators," Oxford Bulletin of Economic and Statistics, 1987, 49, pp. 431-34. 
[3] Axelrod, Robert. "The Dissemination of Culture: A Model with Local Convergence and Global Polarization", Journal of Conflict Resolution, 1997, 41(2), pp. 203-26.

[4] Bordo, Michael; Eichengreen, Barry; Klingebiel, Daniela and Martinez-Peria, Maria Soledad. "Is the Crisis Problem Growing More Severe?", http://elsa.berkeley.edu/users/eichengr/research/EconomicPolicy.pdf., 2000 .

[5] Bordo, Michael; Eichengreen, Barry; Klingebiel, Daniela and Martinez-Peria, Maria Soledad. "Financial Crises: Lessons from the Last 120 Years", Economic Policy, 2001, April.

[6] Chinn, Menzie D. and Ito, Hiro. "What Matters for Financial Development? Capital Controls, Institutions, and Interactions", NBER Working Paper No. 11370, 2005.

[7] Demirgüç-Kunt, Asli and Detragiache, Enrica. "Financial Liberalisation and Financial Fragility", Worldbank Policy Research Working Paper Series No. 1917, 1998.

[8] Fernandez, Raquel and Rodrik, Dani. "Resistance to Reform: Status Quo Bias in the Presence of Individual-Specific Uncertainty", American Economic Review, 1991, 81(5), pp. 1146-55.

[9] Heston, Alan; Summers, Robert and Aten, Bettina. Penn world table version 6.1, Center for International Comparisons at the University of Pennsylvania (CICUP), 2002, October.

[10] Huang, Yongfu. "What Determines Financial Development?" Bristol Economics Discussion Papers No. 05/580, 2005a.

[11] Huang, Yongfu. "Will Political Liberalisation Bring about Financial Development?" Bristol Economics Discussion Papers No. 05/578, $2005 b$.

[12] IMF. International financial statistics (2005). 
[13] Marshall, Monty G. and Jaggers, Keith. Polity IV project country reports, CIDUM, University of Maryland, 2003.

[14] McKinnon, Ronald I. Money and capital in economic development, Washington D.C. Brookings Institution, 1973.

[15] Nickel, Stephen J. "Biases in Dynamic Models with Fixed Effects", Econometrica, 1981, 49, pp. 1417-1426.

[16] Pesaran, M. Hashem. "Estimation and Inference in Large Heterogeneous Panels with a Multifactor Error Structure", Econometrica (forthcoming) 2006a.

[17] Pesaran, M. Hashem. "A Simple Panel Unit Root Test in the Presence of Cross Section Dependence", Cambridge University DAE Working Paper, No. 0346, 2006b.

[18] Phillips, Peter C. B. and Sul, Donggyu. "Dynamic Panel Testing and Homogeneity Testing under Cross Section Dependence", Econometrics Journal, 2003, 6, pp. 217-59.

[19] Quinn, Dennis P. and Inclán, Carla. "The Origins of Financial Openness: A Study of Current and Capital Account Liberalization", American Journal of Political Science, 1997, 41(3), pp. 771-813.

[20] Shaw, Edward S. Financial deepening in economic development, New York, Oxford University Press, 1973.

[21] Simmons, Beth A. and Elkins, Zachary. "The Globalization of Liberalization: Policy Diffusion in the International Political Economy", American Political Science Review, 2004, 98(1), pp. 171-89.

[22] Summers, Lawrence H. "International Financial Crises: Causes, Prevention, and Cures". American Economic Review Papers and Proceedings, 2000, 90(2), pp. 1-16.

[23] World Bank. World development indicators (2004).

[24] World Bank. Database of political institutions (2005). 
Table 1. Within Estimates: Benchmark Specification (Equation 2)

A. $F L_{i, t-1} \times\left(1-F L_{i, t-1}\right)$ reported

\begin{tabular}{|c|c|c|c|c|c|c|}
\hline Estimators & WG & WG & WG & CCEP & CCEP & CCEP \\
\hline$F L_{i, t-1} \times\left(1-F L_{i, t-1}\right)$ & $\begin{array}{l}0.083 \\
{[0.038]^{* *}}\end{array}$ & $\begin{array}{l}0.098 \\
{[0.038]^{* * *}}\end{array}$ & $\begin{array}{l}0.083 \\
{[0.039]^{* *}}\end{array}$ & $\begin{array}{l}-0.026 \\
{[0.130]}\end{array}$ & $\begin{array}{l}-0.011 \\
{[0.113]}\end{array}$ & $\begin{array}{l}0.013 \\
{[0.126]}\end{array}$ \\
\hline$R E G_{-} F L_{i, t-1}-F L_{i, t-1}$ & $\begin{array}{l}0.076 \\
{[0.016]^{* * *}}\end{array}$ & $\begin{array}{l}0.070 \\
{[0.016]^{* * *}}\end{array}$ & $\begin{array}{l}0.083 \\
{[0.017]^{\star * *}}\end{array}$ & $\begin{array}{l}0.097 \\
{[0.034]^{* * *}}\end{array}$ & $\begin{array}{l}0.115 \\
{[0.034]^{* * *}}\end{array}$ & $\begin{array}{l}0.173 \\
{[0.052]^{* * *}}\end{array}$ \\
\hline$B O P_{i t}$ & & $\begin{array}{l}0.017 \\
{[0.006]^{* * *}}\end{array}$ & $\begin{array}{l}0.013 \\
{[0.006]^{* *}}\end{array}$ & & $\begin{array}{l}0.013 \\
{[0.008]^{*}}\end{array}$ & $\begin{array}{l}0.012 \\
{[0.010]}\end{array}$ \\
\hline$B A N K_{i t}$ & & $\begin{array}{l}-0.024 \\
{[0.007]^{* * *}}\end{array}$ & $\begin{array}{l}-0.022 \\
{[0.007]^{* * *}}\end{array}$ & & $\begin{array}{l}-0.028 \\
{[0.011]^{* *}}\end{array}$ & $\begin{array}{l}-0.024 \\
{[0.012]^{* *}}\end{array}$ \\
\hline$R E C E S S I O N_{i t}$ & & $\begin{array}{l}-0.010 \\
{[0.008]}\end{array}$ & $\begin{array}{l}-0.009 \\
{[0.008]}\end{array}$ & & $\begin{array}{l}-0.006 \\
{[0.009]}\end{array}$ & $\begin{array}{l}-0.009 \\
{[0.010]}\end{array}$ \\
\hline$H I N F L_{i t}$ & & $\begin{array}{l}-0.003 \\
{[0.011]}\end{array}$ & $\begin{array}{l}-0.002 \\
{[0.011]}\end{array}$ & & $\begin{array}{l}-0.034 \\
{[0.022]}\end{array}$ & $\begin{array}{l}-0.043 \\
{[0.023]^{*}}\end{array}$ \\
\hline FIRSTYEAR $_{i t}$ & & & $\begin{array}{l}0.011 \\
{[0.006]^{*}}\end{array}$ & & & $\begin{array}{l}0.010 \\
{[0.007]}\end{array}$ \\
\hline$I M F_{i t}$ & & & $\begin{array}{l}0.011 \\
{[0.007]^{*}}\end{array}$ & & & $\begin{array}{l}0.013 \\
{[0.010]}\end{array}$ \\
\hline$U_{S I N T_{i t}}$ & & & $\begin{array}{l}-0.003 \\
{[0.001]^{\star * *}}\end{array}$ & & & $\begin{array}{l}-0.004 \\
{[0.002]^{*}}\end{array}$ \\
\hline$L E F T_{i t}$ & & & $\begin{array}{l}-0.001 \\
{[0.010]}\end{array}$ & & & $\begin{array}{l}-0.020 \\
{[0.014]}\end{array}$ \\
\hline$R I G H T_{i t}$ & & & $\begin{array}{l}0.000 \\
{[0.009]}\end{array}$ & & & $\begin{array}{l}-0.004 \\
{[0.015]}\end{array}$ \\
\hline$O P E N_{i t}$ & & & $\begin{array}{l}0.000 \\
{[0.000]^{*}}\end{array}$ & & & $\begin{array}{l}0.001 \\
{[0.000]}\end{array}$ \\
\hline$D E M O_{i t}$ & & & $\begin{array}{l}-0.013 \\
{[0.014]}\end{array}$ & & & $\begin{array}{l}-0.018 \\
{[0.029]}\end{array}$ \\
\hline Observations & 805 & 805 & 805 & 805 & 805 & 805 \\
\hline Number of country & 35 & 35 & 35 & 35 & 35 & 35 \\
\hline R-squared & 0.03 & 0.05 & 0.07 & 0.22 & 0.25 & 0.32 \\
\hline
\end{tabular}


B. $F L_{i, t-1}$ and $F L_{i, t-1}^{2}$ reported separately

\begin{tabular}{|c|c|c|c|c|c|c|}
\hline Estimators & WG & WG & WG & CCEP & CCEP & CCEP \\
\hline$F L_{i, t-1}$ & $\begin{array}{l}0.081 \\
{[0.038]^{* *}}\end{array}$ & $\begin{array}{l}0.096 \\
{[0.038]^{* *}}\end{array}$ & $\begin{array}{l}0.074 \\
{[0.040]^{*}}\end{array}$ & $\begin{array}{l}-0.204 \\
{[0.094]^{* *}}\end{array}$ & $\begin{array}{l}-0.191 \\
{[0.091]^{* *}}\end{array}$ & $\begin{array}{l}-0.199 \\
{[0.112]^{*}}\end{array}$ \\
\hline$F L_{i, t-1}{ }^{2}$ & $\begin{array}{l}-0.104 \\
{[0.043]^{* *}}\end{array}$ & $\begin{array}{l}-0.113 \\
{[0.043]^{* * *}}\end{array}$ & $\begin{array}{l}-0.113 \\
{[0.043]^{* * *}}\end{array}$ & $\begin{array}{l}-0.218 \\
{[0.096]^{* *}}\end{array}$ & $\begin{array}{l}-0.226 \\
{[0.085]^{* *}}\end{array}$ & $\begin{array}{l}-0.250 \\
{[0.105]^{* *}}\end{array}$ \\
\hline$R E G_{-} F L_{i, t-1}-F L_{i, t-1}$ & $\begin{array}{l}0.059 \\
{[0.022]^{\star * *}}\end{array}$ & $\begin{array}{l}0.058 \\
{[0.022]^{* * *}}\end{array}$ & $\begin{array}{l}0.058 \\
{[0.023]^{* *}}\end{array}$ & $\begin{array}{l}-0.137 \\
{[0.032]^{\star * *}}\end{array}$ & $\begin{array}{l}-0.113 \\
{[0.042]^{* *}}\end{array}$ & $\begin{array}{l}-0.085 \\
{[0.065]}\end{array}$ \\
\hline$B O P_{i t}$ & & $\begin{array}{l}0.016 \\
{[0.006]^{* * *}}\end{array}$ & $\begin{array}{l}0.011 \\
{[0.006]^{*}}\end{array}$ & & $\begin{array}{l}0.007 \\
{[0.007]}\end{array}$ & $\begin{array}{l}0.006 \\
{[0.009]}\end{array}$ \\
\hline$B A N K_{i t}$ & & $\begin{array}{l}-0.024 \\
{[0.007]^{* * *}}\end{array}$ & $\begin{array}{l}-0.020 \\
{[0.007]^{* * *}}\end{array}$ & & $\begin{array}{l}-0.023 \\
{[0.010]^{* *}}\end{array}$ & $\begin{array}{l}-0.021 \\
{[0.010]^{*}}\end{array}$ \\
\hline$R_{E C E S S I O N}$ & & $\begin{array}{l}-0.010 \\
{[0.008]}\end{array}$ & $\begin{array}{l}-0.009 \\
{[0.008]}\end{array}$ & & $\begin{array}{l}-0.002 \\
{[0.008]}\end{array}$ & $\begin{array}{l}-0.006 \\
{[0.010]}\end{array}$ \\
\hline$H I N F L_{i t}$ & & $\begin{array}{l}-0.003 \\
{[0.011]}\end{array}$ & $\begin{array}{l}-0.002 \\
{[0.011]}\end{array}$ & & $\begin{array}{l}-0.041 \\
{[0.017]^{* *}}\end{array}$ & $\begin{array}{l}-0.044 \\
{[0.019]^{* *}}\end{array}$ \\
\hline FIRSTYEAR $_{i t}$ & & & $\begin{array}{l}0.011 \\
{[0.006]^{*}}\end{array}$ & & & $\begin{array}{l}0.010 \\
{[0.007]}\end{array}$ \\
\hline$I M F_{i t}$ & & & $\begin{array}{l}0.012 \\
{[0.007]^{*}}\end{array}$ & & & $\begin{array}{l}0.014 \\
{[0.010]}\end{array}$ \\
\hline USINT $_{i t}$ & & & $\begin{array}{l}-0.003 \\
{[0.001]^{* * *}}\end{array}$ & & & $\begin{array}{l}-0.003 \\
{[0.003]}\end{array}$ \\
\hline$L E F T_{i t}$ & & & $\begin{array}{l}0.002 \\
{[0.010]}\end{array}$ & & & $\begin{array}{l}-0.019 \\
{[0.012]}\end{array}$ \\
\hline RIGHT it & & & $\begin{array}{l}0.003 \\
{[0.009]}\end{array}$ & & & $\begin{array}{l}-0.001 \\
{[0.012]}\end{array}$ \\
\hline OPEN $_{i t}$ & & & $\begin{array}{l}0.000 \\
{[0.000]^{*}}\end{array}$ & & & $\begin{array}{l}0.001 \\
{[0.000]}\end{array}$ \\
\hline$D E M O_{i t}$ & & & $\begin{array}{l}-0.011 \\
{[0.014]}\end{array}$ & & & $\begin{array}{l}-0.044 \\
{[0.033]}\end{array}$ \\
\hline Observations & 805 & 805 & 805 & 805 & 805 & 805 \\
\hline Number of country & 35 & 35 & 35 & 35 & 35.00 & 35 \\
\hline R-squared & 0.03 & 0.05 & 0.08 & 0.31 & 0.33 & 0.40 \\
\hline
\end{tabular}

Note: 35 countries (original dataset), 1973-1997. Dependent variable is $\Delta F L_{i, t}$. Using normal one-way within groups estimator (WG) and Pesaran (2006a)'s CCEP estimator, Table A/B presents new results corresponding to Table 7 in Abiad and Mody (2005) with the addition of $D E M O_{11}$. Table 2A reports within groups estimates for $F L_{i, t-1} \times\left(1-F L_{i, t-1}\right)$, while Table 2B reports results for $F L_{i, t-1}$ and $F L_{i, t-1}{ }^{2}$ reported separately. The within groups R-squared is reported. Nonrobust standard errors are reported for WG estimates, while panel- robust standard errors are reported for CCEP estimates. * significant at $10 \%$; ${ }^{* *}$ significant at $5 \%$; ${ }^{* *}$ significant at $1 \%$. 
Table 2. Within Estimates: Alternative Specification (Equation 3 and 4)

\begin{tabular}{|c|c|c|c|c|}
\hline Estimators & $\overline{W G}$ & $\overline{W G}$ & CCEP & CCEP \\
\hline$F L_{i, t-1}$ & $\begin{array}{l}0.074 \\
{[0.040]^{*}}\end{array}$ & $\begin{array}{l}0.092 \\
{[0.040]^{* *}}\end{array}$ & $\begin{array}{l}-0.199 \\
{[0.112]^{*}}\end{array}$ & $\begin{array}{l}-0.392 \\
{[0.106]^{* * *}}\end{array}$ \\
\hline$\left(F L_{i, t-1}\right)^{2}$ & $\begin{array}{l}-0.113 \\
{[0.043]^{* * *}}\end{array}$ & $\begin{array}{l}-0.201 \\
{[0.053]^{* * *}}\end{array}$ & $\begin{array}{l}-0.25 \\
{[0.105]^{\star *}}\end{array}$ & $\begin{array}{l}-0.235 \\
{[0.138]^{*}}\end{array}$ \\
\hline$F L_{i, t-1} \times Y_{i, t-1}$ & & $\begin{array}{l}0.007 \\
{[0.002]^{* * *}}\end{array}$ & & $\begin{array}{l}0.016 \\
{[0.010]}\end{array}$ \\
\hline$R E G_{-} F L_{i, t-1}-F L_{i, t-1}$ & $\begin{array}{l}0.058 \\
{[0.023]^{* *}}\end{array}$ & $\begin{array}{l}0.063 \\
{[0.023]^{* * *}}\end{array}$ & $\begin{array}{l}-0.085 \\
{[0.065]}\end{array}$ & $\begin{array}{l}0.062 \\
{[0.091]}\end{array}$ \\
\hline$B O P_{i t}$ & $\begin{array}{l}0.011 \\
{[0.006]^{*}}\end{array}$ & $\begin{array}{l}0.011 \\
{[0.006]^{*}}\end{array}$ & $\begin{array}{l}0.006 \\
{[0.009]}\end{array}$ & $\begin{array}{l}-0.005 \\
{[0.010]}\end{array}$ \\
\hline$B A N K_{i t}$ & $\begin{array}{l}-0.020 \\
{[0.007]^{* * *}}\end{array}$ & $\begin{array}{l}-0.022 \\
{[0.007]^{\star * *}}\end{array}$ & $\begin{array}{l}-0.021 \\
{[0.010]^{*}}\end{array}$ & $\begin{array}{l}-0.022 \\
{[0.011]^{* *}}\end{array}$ \\
\hline$R E C E S S I O N_{i t}$ & $\begin{array}{l}-0.009 \\
{[0.008]}\end{array}$ & $\begin{array}{l}-0.008 \\
{[0.008]}\end{array}$ & $\begin{array}{l}-0.006 \\
{[0.010]}\end{array}$ & $\begin{array}{l}-0.012 \\
{[0.010]}\end{array}$ \\
\hline$H I N F L_{i t}$ & $\begin{array}{l}-0.002 \\
{[0.011]}\end{array}$ & $\begin{array}{l}-0.005 \\
{[0.011]}\end{array}$ & $\begin{array}{l}-0.044 \\
{[0.019]^{* *}}\end{array}$ & $\begin{array}{l}-0.017 \\
{[0.028]}\end{array}$ \\
\hline$F_{I R S T Y E A R}$ & $\begin{array}{l}0.011 \\
{[0.006]^{*}}\end{array}$ & $\begin{array}{l}0.011 \\
{[0.006]^{*}}\end{array}$ & $\begin{array}{l}0.01 \\
{[0.007]}\end{array}$ & $\begin{array}{l}0.008 \\
{[0.007]}\end{array}$ \\
\hline$I M F_{i t}$ & $\begin{array}{l}0.012 \\
{[0.007]^{*}}\end{array}$ & $\begin{array}{l}0.012 \\
{[0.007]^{*}}\end{array}$ & $\begin{array}{l}0.014 \\
{[0.010]}\end{array}$ & $\begin{array}{l}0.012 \\
{[0.010]}\end{array}$ \\
\hline$U_{S I N T}$ & $\begin{array}{l}-0.003 \\
{[0.001]^{* * *}}\end{array}$ & $\begin{array}{l}-0.003 \\
{[0.001]^{* * *}}\end{array}$ & $\begin{array}{l}-0.003 \\
{[0.003]}\end{array}$ & $\begin{array}{l}-0.001 \\
{[0.002]}\end{array}$ \\
\hline$L E F T_{i t}$ & $\begin{array}{l}0.002 \\
{[0.010]}\end{array}$ & $\begin{array}{l}0.000 \\
{[0.010]}\end{array}$ & $\begin{array}{l}-0.019 \\
{[0.012]}\end{array}$ & $\begin{array}{l}-0.019 \\
{[0.016]}\end{array}$ \\
\hline$R I G H T_{i t}$ & $\begin{array}{l}0.003 \\
{[0.009]}\end{array}$ & $\begin{array}{l}0.003 \\
{[0.009]}\end{array}$ & $\begin{array}{l}-0.001 \\
{[0.012]}\end{array}$ & $\begin{array}{l}-0.018 \\
{[0.017]}\end{array}$ \\
\hline$O P E N_{i t}$ & $\begin{array}{l}0.000 \\
{[0.000]^{*}}\end{array}$ & $\begin{array}{l}0.000 \\
{[0.000]^{* *}}\end{array}$ & $\begin{array}{l}0.001 \\
{[0.000]}\end{array}$ & $\begin{array}{l}0.001 \\
{[0.001]}\end{array}$ \\
\hline$D E M O_{i t}$ & $\begin{array}{l}-0.011 \\
{[0.014]}\end{array}$ & $\begin{array}{l}-0.010 \\
{[0.014]}\end{array}$ & $\begin{array}{l}-0.044 \\
{[0.033]}\end{array}$ & $\begin{array}{l}-0.089 \\
{[0.049]^{*}}\end{array}$ \\
\hline Observations & 805 & 805 & 805 & 805 \\
\hline Number of country & 35 & 35 & 35 & 35 \\
\hline R-squared & 0.08 & 0.09 & 0.4 & 0.55 \\
\hline
\end{tabular}

Note: This table, based on the original dataset, presents new results corresponding to the Table 8 in Abiad and Mody (2005) with the addition of $D E M O_{i t}$. See Table 1 for further notes. 
Table 3. Within Estimates: Alternative Specification (Equation 5)

\begin{tabular}{|c|c|c|}
\hline Estimators & WG & CCEP \\
\hline$F L_{i, t-1}$ & $\begin{array}{l}-0.009 \\
{[0.072]}\end{array}$ & $\begin{array}{l}-0.045 \\
{[0.315]}\end{array}$ \\
\hline$\left(\begin{array}{ll}F L_{i, t-1}\end{array}\right)^{2}$ & $\begin{array}{l}-0.011 \\
{[0.073]}\end{array}$ & $\begin{array}{l}-0.344 \\
{[0.229]}\end{array}$ \\
\hline$R E G_{-} F L_{i, t-1}-F L_{i, t-1}$ & $\begin{array}{l}0.025 \\
{[0.023]}\end{array}$ & $\begin{array}{l}0.054 \\
{[0.098]}\end{array}$ \\
\hline$\left(R E G-F L_{i, t-1}-F L_{i, t-1}\right) \times F L_{i, t-1}$ & $\begin{array}{l}0.330 \\
{[0.086]^{* * *}}\end{array}$ & $\begin{array}{l}-0.098 \\
{[0.300]}\end{array}$ \\
\hline$B O P_{i t}$ & $\begin{array}{l}0.020 \\
{[0.010]^{* *}}\end{array}$ & $\begin{array}{l}0.004 \\
{[0.014]}\end{array}$ \\
\hline$B O P \quad$ it $\times F L_{i, t-1}$ & $\begin{array}{l}-0.029 \\
{[0.019]}\end{array}$ & $\begin{array}{l}-0.029 \\
{[0.028]}\end{array}$ \\
\hline$B A N K \quad$ it & $\begin{array}{l}-0.023 \\
{[0.013]^{*}}\end{array}$ & $\begin{array}{l}-0.01 \\
{[0.017]}\end{array}$ \\
\hline$B A N K{ }_{i t} \times F L_{i, t-1}$ & $\begin{array}{l}0.004 \\
{[0.027]}\end{array}$ & $\begin{array}{l}-0.035 \\
{[0.033]}\end{array}$ \\
\hline RECESSION it & $\begin{array}{l}-0.015 \\
{[0.012]}\end{array}$ & $\begin{array}{l}-0.015 \\
{[0.017]}\end{array}$ \\
\hline RECESSION $\quad{ }_{i t} \times F L_{i, t-1}$ & $\begin{array}{l}0.020 \\
{[0.023]}\end{array}$ & $\begin{array}{l}0.007 \\
{[0.028]}\end{array}$ \\
\hline HINFL it & $\begin{array}{l}0.030 \\
{[0.015]^{*}}\end{array}$ & $\begin{array}{l}0.007 \\
{[0.033]}\end{array}$ \\
\hline$H I N F L_{i t} \times F L_{i, t-1}$ & $\begin{array}{l}-0.156 \\
{[0.043]^{* * *}}\end{array}$ & $\begin{array}{l}-0.117 \\
{[0.091]}\end{array}$ \\
\hline FIRSTYEAR it & $\begin{array}{l}0.028 \\
{[0.010]^{* * *}}\end{array}$ & $\begin{array}{l}0.031 \\
{[0.015]^{* *}}\end{array}$ \\
\hline FIRSTYEAR $_{i t} \times F L_{i, t-1}$ & $\begin{array}{l}-0.049 \\
{[0.020]^{* *}}\end{array}$ & $\begin{array}{l}-0.064 \\
{[0.027]^{* *}}\end{array}$ \\
\hline$I M F_{i t}$ & $\begin{array}{l}0.020 \\
{[0.009]^{* *}}\end{array}$ & $\begin{array}{l}0.023 \\
{[0.012]^{*}}\end{array}$ \\
\hline$I M F_{i t} \times F L_{i, t-1}$ & $\begin{array}{l}-0.050 \\
{[0.026]^{*}}\end{array}$ & $\begin{array}{l}-0.069 \\
{[0.030]^{* *}}\end{array}$ \\
\hline USINT $\quad$ it & $\begin{array}{l}-0.003 \\
{[0.001]^{* * *}}\end{array}$ & $\begin{array}{l}-0.001 \\
{[0.002]}\end{array}$ \\
\hline$L E F T_{\text {it }}$ & $\begin{array}{l}-0.025 \\
{[0.014]^{*}}\end{array}$ & $\begin{array}{l}-0.034 \\
{[0.023]}\end{array}$ \\
\hline$L E F T_{i t} \times F L_{i, t-1}$ & $\begin{array}{l}0.068 \\
{[0.034]^{* *}}\end{array}$ & $\begin{array}{l}0.024 \\
{[0.039]}\end{array}$ \\
\hline RIGHT it & $\begin{array}{l}0.006 \\
{[0.012]}\end{array}$ & $\begin{array}{l}-0.012 \\
{[0.020]}\end{array}$ \\
\hline$R I G H T \quad{ }_{i t} \times F L_{i, t-1}$ & $\begin{array}{l}0.020 \\
{[0.032]}\end{array}$ & $\begin{array}{l}-0.03 \\
{[0.050]}\end{array}$ \\
\hline OPEN it & $\begin{array}{l}0.001 \\
{[0.000]^{* * *}}\end{array}$ & $\begin{array}{l}0.002 \\
{[0.001]}\end{array}$ \\
\hline OPEN ${ }_{i t} \times F L_{i, t-1}$ & $\begin{array}{l}-0.001 \\
{[0.000]^{* * *}}\end{array}$ & $\begin{array}{l}-0.002 \\
{[0.001]}\end{array}$ \\
\hline$D E M O \quad$ it & $\begin{array}{l}-0.030 \\
{[0.018]^{*}}\end{array}$ & $\begin{array}{l}-0.115 \\
{[0.047]^{* *}}\end{array}$ \\
\hline$D E M O_{i t} \times F L_{i, t-1}$ & $\begin{array}{l}0.002 \\
{[0.002]}\end{array}$ & $\begin{array}{l}0.007 \\
{[0.004]^{*}}\end{array}$ \\
\hline Observations & 805 & 805 \\
\hline Number of country & 35 & 35 \\
\hline R-squared & 0.14 & 0.57 \\
\hline
\end{tabular}

Note: This table, based on the original dataset, presents new results corresponding to the Table 9 in Abiad and Mody (2005) with the addition of $D E M O_{i t}$. See Table 1 for further notes. 
Table 4. Augmented dataset with Chinn-Ito measure (2005)

A. Within estimates corresponding to Table 1B

\begin{tabular}{|c|c|c|c|c|c|c|}
\hline Estimators & WG & WG & $\overline{W G}$ & CCEP & CCEP & CCEP \\
\hline$F L_{i, t-1}$ & $\begin{array}{l}-0.168 \\
{[0.044]^{* * *}}\end{array}$ & $\begin{array}{l}-0.170 \\
{[0.044]^{* * *}}\end{array}$ & $\begin{array}{l}-0.185 \\
{[0.048]^{* * *}}\end{array}$ & $\begin{array}{l}-0.204 \\
{[0.069]^{* * *}}\end{array}$ & $\begin{array}{l}-0.214 \\
{[0.068]^{* * *}}\end{array}$ & $\begin{array}{l}-0.301 \\
{[0.086]^{* * *}}\end{array}$ \\
\hline$F L_{i, t-1}^{2}$ & $\begin{array}{l}0.052 \\
{[0.037]}\end{array}$ & $\begin{array}{l}0.053 \\
{[0.037]}\end{array}$ & $\begin{array}{l}0.070 \\
{[0.039]^{*}}\end{array}$ & $\begin{array}{l}0.087 \\
{[0.049]^{*}}\end{array}$ & $\begin{array}{l}0.092 \\
{[0.049]^{*}}\end{array}$ & $\begin{array}{l}0.164 \\
{[0.058]^{* * *}}\end{array}$ \\
\hline$R E G_{-} F L_{i, t-1}-F L_{i, t-1}$ & $\begin{array}{l}-0.016 \\
{[0.027]}\end{array}$ & $\begin{array}{l}-0.018 \\
{[0.027]}\end{array}$ & $\begin{array}{l}0.007 \\
{[0.030]}\end{array}$ & $\begin{array}{l}0.048 \\
{[0.036]}\end{array}$ & $\begin{array}{l}0.044 \\
{[0.037]}\end{array}$ & $\begin{array}{l}0.063 \\
{[0.046]}\end{array}$ \\
\hline$B O P_{i t}$ & & $\begin{array}{l}0.002 \\
{[0.007]}\end{array}$ & $\begin{array}{l}0.003 \\
{[0.007]}\end{array}$ & & $\begin{array}{l}-0.005 \\
{[0.007]}\end{array}$ & $\begin{array}{l}-0.006 \\
{[0.008]}\end{array}$ \\
\hline$B A N K_{i t}$ & & $\begin{array}{l}-0.010 \\
{[0.009]}\end{array}$ & $\begin{array}{l}-0.012 \\
{[0.009]}\end{array}$ & & $\begin{array}{l}-0.008 \\
{[0.010]}\end{array}$ & $\begin{array}{l}-0.010 \\
{[0.011]}\end{array}$ \\
\hline$R_{E C E S S I O N}$ & & $\begin{array}{l}-0.001 \\
{[0.007]}\end{array}$ & $\begin{array}{l}0.004 \\
{[0.007]}\end{array}$ & & $\begin{array}{l}0.001 \\
{[0.008]}\end{array}$ & $\begin{array}{l}0.002 \\
{[0.009]}\end{array}$ \\
\hline$H_{I N F L_{i t}}$ & & $\begin{array}{l}-0.018 \\
{[0.012]}\end{array}$ & $\begin{array}{l}-0.015 \\
{[0.013]}\end{array}$ & & $\begin{array}{l}-0.009 \\
{[0.017]}\end{array}$ & $\begin{array}{l}-0.007 \\
{[0.018]}\end{array}$ \\
\hline FIRSTYEAR $_{i t}$ & & & $\begin{array}{l}0.000 \\
{[0.007]}\end{array}$ & & & $\begin{array}{l}0.001 \\
{[0.005]}\end{array}$ \\
\hline$I M F_{i t}$ & & & $\begin{array}{l}0.000 \\
{[0.009]}\end{array}$ & & & $\begin{array}{l}0.007 \\
{[0.007]}\end{array}$ \\
\hline USINT $_{i t}$ & & & $\begin{array}{l}-0.005 \\
{[0.001]^{* * *}}\end{array}$ & & & $\begin{array}{l}-0.002 \\
{[0.002]}\end{array}$ \\
\hline$L E F T_{i t}$ & & & $\begin{array}{l}-0.002 \\
{[0.010]}\end{array}$ & & & $\begin{array}{l}-0.010 \\
{[0.010]}\end{array}$ \\
\hline$R I G H T_{i t}$ & & & $\begin{array}{l}0.000 \\
{[0.010]}\end{array}$ & & & $\begin{array}{l}-0.003 \\
{[0.012]}\end{array}$ \\
\hline OPEN $_{i t}$ & & & $\begin{array}{l}0.000 \\
{[0.000]}\end{array}$ & & & $\begin{array}{l}0.000 \\
{[0.000]}\end{array}$ \\
\hline$D E M O_{i t}$ & & & $\begin{array}{l}-0.003 \\
{[0.018]}\end{array}$ & & & $\begin{array}{l}0.004 \\
{[0.027]}\end{array}$ \\
\hline Observations & 1263 & 1262 & 1150 & 1263 & 1262 & 1150 \\
\hline Number of country & 55 & 55 & 53 & 55 & 55 & 53 \\
\hline R-squared & 0.04 & 0.04 & 0.07 & 0.22 & 0.22 & 0.26 \\
\hline
\end{tabular}

Note: 55 countries, 1973-1997. Dependent variable is $\Delta F L_{i, t}$. Using normal one-way within groups estimator (WG) and Pesaran (2006a)'s CCEP estimator, this table, based on a larger dataset associated with the Chinn-Ito measure (2005), presents new results corresponding to the Table 1B. The within groups R-squared is reported. Variable descriptions are presented in the Appendix Table 1. Countries included are listed in the Appendix Table 2. Nonrobust standard errors are reported for WG estimates, while panel- robust standard errors are reported for CCEP estimates. * significant at 10\%; ** significant at $5 \%$; ${ }^{* * *}$ significant at $1 \%$. 
B. Within estimates corresponding to Table 2

\begin{tabular}{|c|c|c|c|c|}
\hline Estimators & WG & WG & CCEP & CCEP \\
\hline$F L_{i, t-1}$ & $\begin{array}{l}-0.185 \\
{[0.048]^{* * *}}\end{array}$ & $\begin{array}{l}-0.180 \\
{[0.048]^{* * *}}\end{array}$ & $\begin{array}{l}-0.301 \\
{[0.086]^{* * *}}\end{array}$ & $\begin{array}{l}-0.375 \\
{[0.122]^{* * *}}\end{array}$ \\
\hline$\left(F L_{i, t-1}\right)^{2}$ & $\begin{array}{l}0.070 \\
{[0.039]^{*}}\end{array}$ & $\begin{array}{l}0.028 \\
{[0.046]}\end{array}$ & $\begin{array}{l}0.164 \\
{[0.058]^{* * *}}\end{array}$ & $\begin{array}{l}0.138 \\
{[0.071]^{*}}\end{array}$ \\
\hline$F L_{i, t-1} \times Y_{i, t-1}$ & & $\begin{array}{l}0.003 \\
{[0.002]^{*}}\end{array}$ & & $\begin{array}{l}0.002 \\
{[0.004]}\end{array}$ \\
\hline$R E G_{-} F L_{i, t-1}-F L_{i, t-1}$ & $\begin{array}{l}0.007 \\
{[0.030]}\end{array}$ & $\begin{array}{l}0.013 \\
{[0.030]}\end{array}$ & $\begin{array}{l}0.063 \\
{[0.046]}\end{array}$ & $\begin{array}{l}0.038 \\
{[0.058]}\end{array}$ \\
\hline$B O P_{i t}$ & $\begin{array}{l}0.003 \\
{[0.007]}\end{array}$ & $\begin{array}{l}0.002 \\
{[0.007]}\end{array}$ & $\begin{array}{l}-0.006 \\
{[0.008]}\end{array}$ & $\begin{array}{l}-0.012 \\
{[0.010]}\end{array}$ \\
\hline$B A N K_{i t}$ & $\begin{array}{l}-0.012 \\
{[0.009]}\end{array}$ & $\begin{array}{l}-0.011 \\
{[0.009]}\end{array}$ & $\begin{array}{l}-0.010 \\
{[0.011]}\end{array}$ & $\begin{array}{l}-0.002 \\
{[0.013]}\end{array}$ \\
\hline RECESSION $_{i t}$ & $\begin{array}{l}0.004 \\
{[0.007]}\end{array}$ & $\begin{array}{l}0.005 \\
{[0.007]}\end{array}$ & $\begin{array}{l}0.002 \\
{[0.009]}\end{array}$ & $\begin{array}{l}0.002 \\
{[0.010]}\end{array}$ \\
\hline$H_{I N F L_{i t}}$ & $\begin{array}{l}-0.015 \\
{[0.013]}\end{array}$ & $\begin{array}{l}-0.018 \\
{[0.013]}\end{array}$ & $\begin{array}{l}-0.007 \\
{[0.018]}\end{array}$ & $\begin{array}{l}0.006 \\
{[0.017]}\end{array}$ \\
\hline FIRSTYEAR $_{i t}$ & $\begin{array}{l}0.000 \\
{[0.007]}\end{array}$ & $\begin{array}{l}0.000 \\
{[0.007]}\end{array}$ & $\begin{array}{l}0.001 \\
{[0.005]}\end{array}$ & $\begin{array}{l}0.000 \\
{[0.006]}\end{array}$ \\
\hline$I M F_{i t}$ & $\begin{array}{l}0.000 \\
{[0.009]}\end{array}$ & $\begin{array}{l}0.000 \\
{[0.009]}\end{array}$ & $\begin{array}{l}0.007 \\
{[0.007]}\end{array}$ & $\begin{array}{l}0.010 \\
{[0.007]}\end{array}$ \\
\hline$U_{S I N T}$ & $\begin{array}{l}-0.005 \\
{[0.001]^{* * *}}\end{array}$ & $\begin{array}{l}-0.005 \\
{[0.001]^{* * *}}\end{array}$ & $\begin{array}{l}-0.002 \\
{[0.002]}\end{array}$ & $\begin{array}{l}-0.002 \\
{[0.002]}\end{array}$ \\
\hline$L E F T_{i t}$ & $\begin{array}{l}-0.002 \\
{[0.010]}\end{array}$ & $\begin{array}{l}-0.004 \\
{[0.010]}\end{array}$ & $\begin{array}{l}-0.010 \\
{[0.010]}\end{array}$ & $\begin{array}{l}-0.013 \\
{[0.011]}\end{array}$ \\
\hline$R I G H T_{i t}$ & $\begin{array}{l}0.000 \\
{[0.010]}\end{array}$ & $\begin{array}{l}-0.002 \\
{[0.010]}\end{array}$ & $\begin{array}{l}-0.003 \\
{[0.012]}\end{array}$ & $\begin{array}{l}-0.008 \\
{[0.017]}\end{array}$ \\
\hline$O P E N_{i t}$ & $\begin{array}{l}0.000 \\
{[0.000]}\end{array}$ & $\begin{array}{l}0.000 \\
{[0.000]}\end{array}$ & $\begin{array}{l}0.000 \\
{[0.000]}\end{array}$ & $\begin{array}{l}0.000 \\
{[0.001]}\end{array}$ \\
\hline$D E M O_{i t}$ & $\begin{array}{l}-0.003 \\
{[0.018]}\end{array}$ & $\begin{array}{l}-0.003 \\
{[0.018]}\end{array}$ & $\begin{array}{l}0.004 \\
{[0.027]}\end{array}$ & $\begin{array}{l}0.007 \\
{[0.033]}\end{array}$ \\
\hline Observations & 1150 & 1150 & 1150 & 1150 \\
\hline Number of country & 53 & 53 & 53 & 53 \\
\hline R-squared & 0.07 & 0.07 & 0.26 & 0.33 \\
\hline
\end{tabular}

Note: See Table 4A for further notes. 
C. Within estimates corresponding to Table 3

\begin{tabular}{|c|c|c|}
\hline Estimators & WG & CCEP \\
\hline$F L_{i, t-1}$ & $\begin{array}{l}-0.360 \\
{[0.096]^{* * *}}\end{array}$ & $\begin{array}{l}-0.681 \\
{[0.255]^{* *}}\end{array}$ \\
\hline$\left(F L_{i, t-1}\right)^{2}$ & $\begin{array}{l}0.255 \\
{[0.089]^{* * *}}\end{array}$ & $\begin{array}{l}0.448 \\
{[0.232]^{*}}\end{array}$ \\
\hline$R E G \quad-F L_{i, t-1}-F L_{i, t-1}$ & $\begin{array}{l}-0.006 \\
{[0.031]}\end{array}$ & $\begin{array}{l}-0.009 \\
{[0.057]}\end{array}$ \\
\hline$\left(R E G-F L_{i, t-1}-F L_{i, t-1}\right) \times F L_{i, t-1}$ & $\begin{array}{l}0.274 \\
{[0.107]^{* *}}\end{array}$ & $\begin{array}{l}0.436 \\
{[0.263]}\end{array}$ \\
\hline$B O P_{i t}$ & $\begin{array}{l}-0.010 \\
{[0.012]}\end{array}$ & $\begin{array}{l}-0.013 \\
{[0.017]}\end{array}$ \\
\hline$B O P_{i t} \times F L_{i, t-1}$ & $\begin{array}{l}0.030 \\
{[0.020]}\end{array}$ & $\begin{array}{l}0.009 \\
{[0.028]}\end{array}$ \\
\hline$B A N K \quad$ it & $\begin{array}{l}-0.010 \\
{[0.014]}\end{array}$ & $\begin{array}{l}-0.002 \\
{[0.024]}\end{array}$ \\
\hline$B A N K_{i t} \times F L_{i, t-1}$ & $\begin{array}{l}0.003 \\
{[0.025]}\end{array}$ & $\begin{array}{l}-0.002 \\
{[0.036]}\end{array}$ \\
\hline RECESSION it & $\begin{array}{l}0.006 \\
{[0.011]}\end{array}$ & $\begin{array}{l}0.003 \\
{[0.012]}\end{array}$ \\
\hline $\operatorname{RECESSION}_{i t} \times F L_{i, t-1}$ & $\begin{array}{l}-0.008 \\
{[0.021]}\end{array}$ & $\begin{array}{l}-0.006 \\
{[0.019]}\end{array}$ \\
\hline HINFL it & $\begin{array}{l}0.041 \\
{[0.018]^{\star *}}\end{array}$ & $\begin{array}{l}0.046 \\
{[0.033]}\end{array}$ \\
\hline HINFL ${ }_{i t} \times F L_{i, t-1}$ & $\begin{array}{l}-0.254 \\
{[0.054]^{* * *}}\end{array}$ & $\begin{array}{l}-0.171 \\
{[0.147]}\end{array}$ \\
\hline FIRSTYEAR it & $\begin{array}{l}-0.008 \\
{[0.011]}\end{array}$ & $\begin{array}{l}-0.009 \\
{[0.009]}\end{array}$ \\
\hline FIRSTYEAR ${ }_{i t} \times F L_{i, t-1}$ & $\begin{array}{l}0.019 \\
{[0.021]}\end{array}$ & $\begin{array}{l}0.019 \\
{[0.017]}\end{array}$ \\
\hline$I M F_{i t}$ & $\begin{array}{l}-0.002 \\
{[0.011]}\end{array}$ & $\begin{array}{l}0.018 \\
{[0.012]}\end{array}$ \\
\hline$I M F_{i t} \times F L_{i, t-1}$ & $\begin{array}{l}0.032 \\
{[0.039]}\end{array}$ & $\begin{array}{l}-0.006 \\
{[0.050]}\end{array}$ \\
\hline USINT it & $\begin{array}{l}-0.005 \\
{[0.001]^{* * *}}\end{array}$ & $\begin{array}{l}-0.003 \\
{[0.002]}\end{array}$ \\
\hline$L E F T_{i t}$ & $\begin{array}{l}-0.019 \\
{[0.016]}\end{array}$ & $\begin{array}{l}-0.045 \\
{[0.028]}\end{array}$ \\
\hline$L E F T_{i t} \times F L_{i, t-1}$ & $\begin{array}{l}0.028 \\
{[0.031]}\end{array}$ & $\begin{array}{l}0.068 \\
{[0.051]}\end{array}$ \\
\hline$R_{I G H T}{ }_{i t}$ & $\begin{array}{l}0.004 \\
{[0.015]}\end{array}$ & $\begin{array}{l}-0.015 \\
{[0.031]}\end{array}$ \\
\hline$R I G H T_{i t} \times F L_{i, t-1}$ & $\begin{array}{l}-0.011 \\
{[0.031]}\end{array}$ & $\begin{array}{l}0.022 \\
{[0.048]}\end{array}$ \\
\hline OPEN it & $\begin{array}{l}0.001 \\
{[0.000]^{*}}\end{array}$ & $\begin{array}{l}0.000 \\
{[0.001]}\end{array}$ \\
\hline$O P E N_{i t} \times F L_{i, t-1}$ & $\begin{array}{l}0.000 \\
{[0.000]}\end{array}$ & $\begin{array}{l}0.000 \\
{[0.000]}\end{array}$ \\
\hline$D E M O_{i t}$ & $\begin{array}{l}-0.010 \\
{[0.020]}\end{array}$ & $\begin{array}{l}0.008 \\
{[0.041]}\end{array}$ \\
\hline$D E M O{ }_{i t} \times F L_{i, t-1}$ & $\begin{array}{l}0.001 \\
{[0.002]}\end{array}$ & $\begin{array}{l}0.000 \\
{[0.007]}\end{array}$ \\
\hline Observations & 1150 & 1150 \\
\hline Number of country & 53 & 53 \\
\hline R-squared & 0.10 & 0.35 \\
\hline
\end{tabular}

Note: See Table 4A for further notes. 
Appendix Table 1. The Variables (mainly used with the larger dataset)

\begin{tabular}{|c|c|c|}
\hline VARIABLE & DESCRIPTION & $\begin{array}{l}\text { SOURCE } \\
\end{array}$ \\
\hline FL & $\begin{array}{l}\text { It is the financial liberalisation index, produced by rescaling the } \\
\text { Chinn-Ito index to interval }[0,1] \text {. The Chinn-Ito index, the } \\
\text { KAOPEN index, is to measure a country's degree of capital } \\
\text { account openness, taking on higher values the more open the } \\
\text { country is to cross-border capital transactions. }\end{array}$ & Chinn and Ito (2005) \\
\hline Y & GDP per capita in PPP terms. & Penn World Table 6.1 \\
\hline BOP & \multicolumn{2}{|l|}{$\begin{array}{l}\text { As in Abiad and Mody (2005) (originally taken from Bordo et al.B } \\
(2000) \text { ), it is the balance-of-payment crisis variable identified by } \\
\text { "a forced change in parity, abandonment of a pegged exchange } \\
\text { rate, or an international rescue," or if an index of exchange } \\
\text { market pressure (a weighted average of exchange rate, reserve, } \\
\text { and interest rate changes) exceeds a critical threshold of one } \\
\text { and a half standard deviations above its mean. It is set equal to } \\
1 \text { if a balance of payment crisis has occurred within the past two } \\
\text { years, and } 0 \text { otherwise. }\end{array}$} \\
\hline BANK & \multicolumn{2}{|l|}{$\begin{array}{l}\text { As in Abiad and Mody (2005) (originally taken from Bordo et al. } \\
\text { (2000)), it is the bankig crisis identified by periods of "financial } \\
\text { distress resulting in the erosion of most or all of aggregate } \\
\text { banking system capital". It is set equal to } 1 \text { if a banking crisis } \\
\text { has occurred within the past two years, and } 0 \text { otherwise. }\end{array}$} \\
\hline RECESSION & $\begin{array}{l}\text { As in Abiad and Mody (2005), it is the recession dummy } \\
\text { variable, set equal to } 1 \text { where the annual real GDP growth rate } \\
\text { is negative, and } 0 \text { otherwise. }\end{array}$ & $\begin{array}{l}\text { Penn World Table } 6.1 \\
\text { (PWT61) (Heston et al., } \\
\text { 2002) }\end{array}$ \\
\hline HINFL & $\begin{array}{l}\text { As in Abiad and Mody (2005), it is the high inflation dummy } \\
\text { variable, set equal to } 1 \text { where the annual inflation exceeds } 50 \% \text {, } \\
\text { and } 0 \text { otherwise. }\end{array}$ & $\begin{array}{l}\text { World Bank World } \\
\text { Development Indicators } \\
\text { (WDI), } 2004\end{array}$ \\
\hline FIRSTYEAR & $\begin{array}{l}\text { Based on the YRSOFFCA vaiable, it is the first year in office } \\
\text { dummy as in Abiad and Mody (2005). }\end{array}$ & $\begin{array}{l}\text { World Bank's Database of } \\
\text { Political Institutions (2005) }\end{array}$ \\
\hline IMF & $\begin{array}{l}\text { As in Abiad and Mody (2005), it is the IMF program dummy } \\
\text { variable constructed using the program dates from the IMF } \\
\text { "History of Lending Arrangements". }\end{array}$ & $\begin{array}{l}\text { Abiad and Mody (2005), } \\
\text { and IMF's "History of } \\
\text { Lending". }\end{array}$ \\
\hline USINST & $\begin{array}{l}\text { As in Abiad and Mody (2005), it is the U. S. Treasury Bill rate } \\
\text { used as the world interest rate. }\end{array}$ & $\begin{array}{l}\text { IMF's International } \\
\text { Financial Statistics (2005) }\end{array}$ \\
\hline LEFT & $\begin{array}{l}\text { As in Abiad and Mody (2005), it denotes the left-wing } \\
\text { government where its associated party is named or described as } \\
\text { "communist", "socialist", "Social Democratic", or "left-wing". }\end{array}$ & $\begin{array}{l}\text { World Bank's Database of } \\
\text { Political Institutions (2005) }\end{array}$ \\
\hline RIGHT & $\begin{array}{l}\text { As in Abiad and Mody (2005), it denotes the left-wing } \\
\text { government where its associated party is named or described as } \\
\text { "conservative", or "right-wing". }\end{array}$ & $\begin{array}{l}\text { World Bank's Database of } \\
\text { Political Institutions (2005) }\end{array}$ \\
\hline OPEN & $\begin{array}{l}\text { The sum of exports and imports over GDP (at current prices), } \\
\text { averaged over 1973-97. }\end{array}$ & Penn World Table 6.1 \\
\hline DEMO & $\begin{array}{l}\text { Index of democracy. It is called combined polity score, the } \\
\text { democracy score minus the autocracy score, averaged over } \\
\text { 1973-97. It is also used with the original dataset. The index has } \\
\text { been converted to range from } 0 \text { to } 1 \text {. }\end{array}$ & $\begin{array}{l}\text { PolityIV Database } \\
\text { (Marshall et al., 2003) }\end{array}$ \\
\hline
\end{tabular}




\section{Appendix Table 2: The list of countries in the augmented dataset}

\begin{tabular}{|c|c|c|c|c|c|}
\hline \multicolumn{2}{|c|}{ East Asia } & \multicolumn{2}{|c|}{ South Asia } & \multicolumn{2}{|c|}{ OECD countries } \\
\hline $\mathrm{CHN}$ & China & BGD & Bangladesh* & AUS & Australia* \\
\hline HKG & Hong Kong & IND & India* & AUT & Austria \\
\hline IDN & Indonesia* & LKA & Sri Lanka* & BEL & Belgium \\
\hline KOR & \multicolumn{2}{|c|}{ Korea, Republic of*NPL } & $\mathrm{Nepal}^{*}$ & CAN & Canada* \\
\hline MYS & Malaysia** & \multirow[t]{6}{*}{ PAK } & Pakistan* & CHE & Switzerland \\
\hline PHL & Philippines* & & & DEU & Germany* \\
\hline SGP & Singapore* & & & DNK & Denmark \\
\hline THA & Thailand* & & & ESP & Spain \\
\hline TWN & Taiwan* & & & FIN & Finland \\
\hline & & & & FRA & France* \\
\hline \multicolumn{2}{|c|}{ Latin America \& Caribbean } & \multicolumn{2}{|c|}{ Middle East \& Africa } & GBR & United Kingdom* \\
\hline ARG & Argentina* & EGY & Egypt* & GRC & Greece \\
\hline BRA & Brazil $^{*}$ & GHA & Ghana* & IRL & Ireland \\
\hline $\mathrm{CHL}$ & Chile* & ISR & Israel $^{*}$ & ISL & Iceland \\
\hline COL & Colombia* & MAR & Morocco* & ITA & Italy* \\
\hline CRI & Costa Rica & NGA & Nigeria & JPN & Japan* \\
\hline $\mathrm{ECU}$ & Ecuador & $\mathrm{ZAF}$ & South Africa* & NLD & Netherlands \\
\hline JAM & Jamaica & ZWE & Zimbabwe* & NOR & Norway \\
\hline MEX & Mexico* & & & NZL & New Zealand* \\
\hline PER & Peru* & & & PRT & Portugal \\
\hline PRY & Paraguay & & & SWE & Sweden \\
\hline URY & Uruguay & & & TUR & Turkey* \\
\hline VEN & Venezuela* & & & USA & USA* $^{*}$ \\
\hline
\end{tabular}

Note: Countries with * are in the original dataset of Abiad and Mody (2005).

\section{Appendix Table 3. Unit Root Test in Heterogeneous Panels}

\begin{tabular}{l|cc|cc|cc}
\hline \hline \multirow{2}{*}{$\begin{array}{l}\text { Variables } \\
\text { Trend }\end{array}$} & \multicolumn{2}{c|}{ FL } & \multicolumn{3}{c|}{ GDP } & \multicolumn{2}{c}{ OPEN } \\
\cline { 2 - 7 } Maddala and Wu (1999)'s Fisher test & Yes & No & Yes & No & Yes & No \\
\hline Pesaran (2006b)'s cross sectionally & 43.82 & 25.39 & 77.84 & 52.81 & 75.23 & 64.11 \\
augmented Fisher test & {$[0.99]$} & {$[1.00]$} & {$[0.24]$} & {$[0.94]$} & {$[0.31]$} & {$[0.68]$} \\
\hline \hline
\end{tabular}

Note: Maddala and Wu (1999)'s Fisher test is for the case of cross sectionally independent error. Under the null of a unit root, the test statistic is asymptotically distributed as a standard normal. Pesaran (2006b)'s test is the Maddala and Wu (1999)'s Fisher test applied to the cross sectionally augmented DickeyFuller regression. The $10 \%$ critical values provided by H.M. Pesaran for the pair of $\mathrm{N}=30$ and $\mathrm{T}=30$ is 82.89 with a trend and 82.18 without a trend. 


\section{Appendix Table 4. Corrected version of Tables 7, 8 and 9 in Abiad and Mody (2005)}

A. Corrected version of Table 7 in Abiad and Mody (2005)

\begin{tabular}{|c|c|c|c|c|c|c|}
\hline Country dummy included & No & No & No & Yes & Yes & Yes \\
\hline$F L_{i, t-1} \times\left(1-F L_{i, t-1}\right)$ & $\begin{array}{l}3.933 \\
{[4.39]^{* * *}}\end{array}$ & $\begin{array}{l}4.562 \\
{[4.94]^{* * *}}\end{array}$ & $\begin{array}{l}4.106 \\
{[4.48]^{* * *}}\end{array}$ & $\begin{array}{l}6.794 \\
{[4.44]^{\star * *}}\end{array}$ & $\begin{array}{l}7.284 \\
{[4.83]^{* * *}}\end{array}$ & $\begin{array}{l}6.574 \\
{[4.07]^{\star * *}}\end{array}$ \\
\hline$R E G_{-} F L_{i, t-1}-F L_{i, t-1}$ & $\begin{array}{l}1.032 \\
{[4.18]^{\star * *}}\end{array}$ & $\begin{array}{l}1.050 \\
{[3.76]^{* * *}}\end{array}$ & $\begin{array}{l}1.195 \\
{[3.93]^{* * *}}\end{array}$ & $\begin{array}{l}2.285 \\
{[3.23]^{* * *}}\end{array}$ & $\begin{array}{l}2.089 \\
{[2.71]^{* * *}}\end{array}$ & $\begin{array}{l}2.529 \\
{[3.21]^{\star * *}}\end{array}$ \\
\hline$B O P_{i t}$ & & $\begin{array}{l}0.521 \\
{[2.60]^{\star \star *}}\end{array}$ & $\begin{array}{l}0.430 \\
{[2.21]^{* *}}\end{array}$ & & $\begin{array}{l}0.550 \\
{[2.19]^{\star *}}\end{array}$ & $\begin{array}{l}0.475 \\
{[1.94]^{*}}\end{array}$ \\
\hline$B A N K_{i t}$ & & $\begin{array}{l}-1.020 \\
{[2.74]^{* * *}}\end{array}$ & $\begin{array}{l}-0.983 \\
{[2.67]^{* * *}}\end{array}$ & & $\begin{array}{l}-0.995 \\
{[2.68]^{* * *}}\end{array}$ & $\begin{array}{l}-0.935 \\
{[2.57]^{* *}}\end{array}$ \\
\hline RECESSION & & $\begin{array}{l}-0.018 \\
{[0.05]}\end{array}$ & $\begin{array}{l}0.002 \\
{[0.00]}\end{array}$ & & $\begin{array}{l}-0.055 \\
{[0.15]}\end{array}$ & $\begin{array}{l}-0.026 \\
{[0.07]}\end{array}$ \\
\hline$H I N F L_{i t}$ & & $\begin{array}{l}-0.136 \\
{[0.35]}\end{array}$ & $\begin{array}{l}-0.238 \\
{[0.62]}\end{array}$ & & $\begin{array}{l}-0.317 \\
{[0.50]}\end{array}$ & $\begin{array}{l}-0.302 \\
{[0.48]}\end{array}$ \\
\hline$F_{I R S T Y E A R}$ & & & $\begin{array}{l}0.178 \\
{[0.78]}\end{array}$ & & & $\begin{array}{l}0.234 \\
{[0.87]}\end{array}$ \\
\hline$I M F_{i t}$ & & & $\begin{array}{l}0.327 \\
{[1.81]^{*}}\end{array}$ & & & $\begin{array}{l}0.253 \\
{[0.98]}\end{array}$ \\
\hline$U_{S I N T}$ & & & $\begin{array}{l}-0.071 \\
{[1.82]^{*}}\end{array}$ & & & $\begin{array}{l}-0.090 \\
{[2.13]^{* *}}\end{array}$ \\
\hline$L E F T_{i t}$ & & & $\begin{array}{l}0.282 \\
{[1.14]}\end{array}$ & & & $\begin{array}{l}-0.035 \\
{[0.10]}\end{array}$ \\
\hline$R I G H T_{i t}$ & & & $\begin{array}{l}0.153 \\
{[0.85]}\end{array}$ & & & $\begin{array}{l}-0.132 \\
{[0.39]}\end{array}$ \\
\hline$O P E N_{i t}$ & & & $\begin{array}{l}-0.001 \\
{[1.01]}\end{array}$ & & & $\begin{array}{l}0.009 \\
{[1.14]}\end{array}$ \\
\hline Observations & 805 & 805 & 805 & 805 & 805 & 805 \\
\hline Number of country & 35 & 35 & 35 & 35 & 35 & 35 \\
\hline
\end{tabular}

Note: This is a corrected version of Table 7 in Abiad and Mody (2005) that treats Singapore as an African country and South Africa as an East Asian country. Except for the difference in magnitude, this table shows a similar pattern to the Table 7 in Abiad and Mody (2005). Robust $\mathrm{t}$ statistics in brackets. * significant at $10 \% ;{ }^{* *}$ significant at $5 \%$; ${ }^{* * *}$ significant at $1 \%$. 
B. Corrected version of Table 8 in Abiad and Mody (2005)

\begin{tabular}{|c|c|c|c|c|}
\hline Country dummy included & No & No & Yes & Yes \\
\hline$F L_{i, t-1}$ & $\begin{array}{l}4.110 \\
{[4.49]^{* * *}}\end{array}$ & $\begin{array}{l}4.307 \\
{[4.69]^{* * *}}\end{array}$ & $\begin{array}{l}6.546 \\
{[4.02]^{* * *}}\end{array}$ & $\begin{array}{l}7.189 \\
{[4.34]^{\star * *}}\end{array}$ \\
\hline$\left(F L_{i, t-1}\right)^{2}$ & $\begin{array}{l}-4.052 \\
{[3.94]^{\star * *}}\end{array}$ & $\begin{array}{l}-5.720 \\
{[4.19]^{* * *}}\end{array}$ & $\begin{array}{l}-6.638 \\
{[3.35]^{* * *}}\end{array}$ & $\begin{array}{l}-9.893 \\
{[3.90]^{* * *}}\end{array}$ \\
\hline$F L_{i, t-1} \times Y_{i, t-1}$ & & $\begin{array}{l}0.095 \\
{[2.34]^{* *}}\end{array}$ & & $\begin{array}{l}0.247 \\
{[2.55]^{\star *}}\end{array}$ \\
\hline$R E G_{-} F L_{i, t-1}-F L_{i, t-1}$ & $\begin{array}{l}1.231 \\
{[2.72]^{* * *}}\end{array}$ & $\begin{array}{l}0.965 \\
{[1.88]^{*}}\end{array}$ & $\begin{array}{l}2.465 \\
{[2.09]^{* *}}\end{array}$ & $\begin{array}{l}2.714 \\
{[2.45]^{\star *}}\end{array}$ \\
\hline$B O P_{i t}$ & $\begin{array}{l}0.429 \\
{[2.19]^{* *}}\end{array}$ & $\begin{array}{l}0.476 \\
{[2.40]^{* *}}\end{array}$ & $\begin{array}{l}0.473 \\
{[2.02]^{* *}}\end{array}$ & $\begin{array}{l}0.457 \\
{[1.95]^{*}}\end{array}$ \\
\hline$B A N K_{i t}$ & $\begin{array}{l}-0.985 \\
{[2.70]^{* * *}}\end{array}$ & $\begin{array}{l}-0.976 \\
{[2.70]^{* * *}}\end{array}$ & $\begin{array}{l}-0.932 \\
{[2.70]^{* * *}}\end{array}$ & $\begin{array}{l}-1.007 \\
{[2.92]^{* * *}}\end{array}$ \\
\hline RECESSION $i t$ & $\begin{array}{l}-0.002 \\
{[0.00]}\end{array}$ & $\begin{array}{l}-0.005 \\
{[0.01]}\end{array}$ & $\begin{array}{l}-0.027 \\
{[0.07]}\end{array}$ & $\begin{array}{l}0.001 \\
{[0.00]}\end{array}$ \\
\hline$H I N F L_{i t}$ & $\begin{array}{l}-0.235 \\
{[0.63]}\end{array}$ & $\begin{array}{l}-0.206 \\
{[0.53]}\end{array}$ & $\begin{array}{l}-0.303 \\
{[0.48]}\end{array}$ & $\begin{array}{l}-0.398 \\
{[0.64]}\end{array}$ \\
\hline FIRSTYEAR $_{i t}$ & $\begin{array}{l}0.178 \\
{[0.78]}\end{array}$ & $\begin{array}{l}0.141 \\
{[0.62]}\end{array}$ & $\begin{array}{l}0.233 \\
{[0.86]}\end{array}$ & $\begin{array}{l}0.245 \\
{[0.91]}\end{array}$ \\
\hline$I M F_{i t}$ & $\begin{array}{l}0.332 \\
{[1.74]^{*}}\end{array}$ & $\begin{array}{l}0.414 \\
{[2.12]^{* *}}\end{array}$ & $\begin{array}{l}0.255 \\
{[0.96]}\end{array}$ & $\begin{array}{l}0.288 \\
{[1.06]}\end{array}$ \\
\hline$U_{S I N T}$ & $\begin{array}{l}-0.070 \\
{[1.80]^{*}}\end{array}$ & $\begin{array}{l}-0.074 \\
{[1.87]^{*}}\end{array}$ & $\begin{array}{l}-0.090 \\
{[2.07]^{* *}}\end{array}$ & $\begin{array}{l}-0.086 \\
{[1.99]^{* *}}\end{array}$ \\
\hline$L E F T_{i t}$ & $\begin{array}{l}0.280 \\
{[1.15]}\end{array}$ & $\begin{array}{l}0.190 \\
{[0.82]}\end{array}$ & $\begin{array}{l}-0.029 \\
{[0.08]}\end{array}$ & $\begin{array}{l}-0.098 \\
{[0.28]}\end{array}$ \\
\hline$R I G H T_{i t}$ & $\begin{array}{l}0.146 \\
{[0.77]}\end{array}$ & $\begin{array}{l}0.153 \\
{[0.84]}\end{array}$ & $\begin{array}{l}-0.125 \\
{[0.38]}\end{array}$ & $\begin{array}{l}-0.072 \\
{[0.21]}\end{array}$ \\
\hline$O P E N_{i t}$ & $\begin{array}{l}-0.001 \\
{[1.00]}\end{array}$ & $\begin{array}{l}0.000 \\
{[0.04]}\end{array}$ & $\begin{array}{l}0.009 \\
{[1.14]}\end{array}$ & $\begin{array}{l}0.013 \\
{[1.40]}\end{array}$ \\
\hline $\begin{array}{l}\text { Observations } \\
\text { Number of country }\end{array}$ & $\begin{array}{l}805 \\
35\end{array}$ & $\begin{array}{l}805 \\
35\end{array}$ & $\begin{array}{l}805 \\
35\end{array}$ & $\begin{array}{l}805 \\
35\end{array}$ \\
\hline
\end{tabular}

Note: This table corresponds to the Table 8 in Abiad and Mody (2005) that treats Singapore as an African country and South Africa as an East Asian country, and consequently indicates that IMF in column 1 and REG_FL-FL in column 2 and 3 are insignificant. Robust $t$ statistics in brackets. * significant at $10 \% ; * *$ significant at $5 \%$; $* * *$ significant at $1 \%$. 


\begin{tabular}{|c|c|c|}
\hline Country dummy included & $\mathrm{No}$ & Yes \\
\hline$F L_{i, t-1}$ & $\begin{array}{l}3.719 \\
{[2.16]^{\star *}}\end{array}$ & $\begin{array}{l}3.475 \\
{[1.61]}\end{array}$ \\
\hline$\left(F L_{i, t-1}\right)^{2}$ & $\begin{array}{l}-3.827 \\
{[2.19]^{* *}}\end{array}$ & $\begin{array}{l}-1.82 \\
{[0.70]}\end{array}$ \\
\hline$R E G_{-} F L_{i, t-1}-F L_{i, t-1}$ & $\begin{array}{l}0.508 \\
{[0.81]}\end{array}$ & $\begin{array}{l}1.459 \\
{[1.21]}\end{array}$ \\
\hline$\left(R E G-F L_{i, t-1}-F L_{i, t-1}\right) \times F L_{i, t-1}$ & $\begin{array}{l}2.87 \\
{[1.51]}\end{array}$ & $\begin{array}{l}10.256 \\
{[3.95]^{* * *}}\end{array}$ \\
\hline$B O P_{i t}$ & $\begin{array}{l}0.811 \\
{[2.69]^{* * *}}\end{array}$ & $\begin{array}{l}0.809 \\
{[1.89]^{*}}\end{array}$ \\
\hline$B O P_{i t} \times F L_{i, t-1}$ & $\begin{array}{l}-0.892 \\
{[1.47]}\end{array}$ & $\begin{array}{l}-0.989 \\
{[1.11]}\end{array}$ \\
\hline$B A N K_{i t}$ & $\begin{array}{l}-0.883 \\
{[1.65]^{*}}\end{array}$ & $\begin{array}{l}-1.043 \\
{[1.85]^{*}}\end{array}$ \\
\hline$B A N K_{i t} \times F L_{i, t-1}$ & $\begin{array}{l}-0.093 \\
{[0.09]}\end{array}$ & $\begin{array}{l}0.016 \\
{[0.01]}\end{array}$ \\
\hline $\operatorname{RECESSION~}_{i t}$ & $\begin{array}{l}-0.487 \\
{[1.12]}\end{array}$ & $\begin{array}{l}-0.503 \\
{[0.91]}\end{array}$ \\
\hline RECESSION $\quad{ }_{i t} \times F L_{i, t-1}$ & $\begin{array}{l}1.235 \\
{[1.43]}\end{array}$ & $\begin{array}{l}1.164 \\
{[1.21]}\end{array}$ \\
\hline HINFL $_{i t}$ & $\begin{array}{l}0.292 \\
{[0.64]}\end{array}$ & $\begin{array}{l}0.37 \\
{[0.50]}\end{array}$ \\
\hline$H I N F L_{i t} \times F L_{i, t-1}$ & $\begin{array}{l}-2.203 \\
{[1.65]^{*}}\end{array}$ & $\begin{array}{l}-3.471 \\
{[2.35]^{* *}}\end{array}$ \\
\hline FIRSTYEAR it & $\begin{array}{l}0.566 \\
{[1.98]^{* *}}\end{array}$ & $\begin{array}{l}0.592 \\
{[1.86]^{*}}\end{array}$ \\
\hline FIRSTYEAR $\quad$ it $\times F L_{i, t-1}$ & $\begin{array}{l}-1.163 \\
{[1.84]^{*}}\end{array}$ & $\begin{array}{l}-1.055 \\
{[1.45]}\end{array}$ \\
\hline$I M F_{i t}$ & $\begin{array}{l}0.775 \\
{[2.94]^{\star * *}}\end{array}$ & $\begin{array}{l}0.65 \\
{[1.83]^{*}}\end{array}$ \\
\hline$I M F_{i t} \times F L_{i, t-1}$ & $\begin{array}{l}-1.523 \\
{[2.26]^{* *}}\end{array}$ & $\begin{array}{l}-1.741 \\
{[1.94]^{*}}\end{array}$ \\
\hline USINT $_{i t}$ & $\begin{array}{l}-0.078 \\
{[1.93]^{*}}\end{array}$ & $\begin{array}{l}-0.091 \\
{[2.10]^{* *}}\end{array}$ \\
\hline $\operatorname{LEFT}_{i t}$ & $\begin{array}{l}-0.116 \\
{[0.29]}\end{array}$ & $\begin{array}{l}-0.616 \\
{[1.16]}\end{array}$ \\
\hline$L E F T_{i t} \times F L_{i, t-1}$ & $\begin{array}{l}1.049 \\
{[1.01]}\end{array}$ & $\begin{array}{l}1.282 \\
{[1.09]}\end{array}$ \\
\hline$R_{I G H T}{ }_{i t}$ & $\begin{array}{l}0.257 \\
{[0.87]}\end{array}$ & $\begin{array}{l}0.192 \\
{[0.50]}\end{array}$ \\
\hline$R I G H T_{i t} \times F L_{i, t-1}$ & $\begin{array}{l}0.087 \\
{[0.09]}\end{array}$ & $\begin{array}{l}-0.221 \\
{[0.19]}\end{array}$ \\
\hline$O P E N_{i t}$ & $\begin{array}{l}3.719 \\
{[2.16]^{* *}}\end{array}$ & $\begin{array}{l}3.475 \\
{[1.61]}\end{array}$ \\
\hline$O P E N_{i t} \times F L_{i, t-1}$ & $\begin{array}{l}-3.827 \\
{[2.19]^{* *}}\end{array}$ & $\begin{array}{l}-1.82 \\
{[0.70]}\end{array}$ \\
\hline Observations & 805 & 805 \\
\hline Number of country & 35 & 35 \\
\hline
\end{tabular}

Note: This table corresponds to the Table 9 in Abiad and Mody (2005) that treats Singapore as an African country and South Africa as an East Asian country, and consequently indicates that (REG_FL$F L) \times F L$ is significant but OPEN and OPEN $\times F L$ are insignificant in column 1, and FL, OPEN and OPEN $\times F L$ are significant in column 2. Robust $\mathrm{t}$ statistics in brackets. * significant at $10 \%$; ${ }^{* *}$ significant at $5 \%$; $* * *$ significant at $1 \%$. 


\section{Appendix Table 5. Error dependence across countries and over time considered separately}

A. Within estimates corresponding to Table 1B

\begin{tabular}{|c|c|c|c|c|c|c|}
\hline Estimators & $\overline{W G}$ & $\overline{\text { WG }}$ & WG & CCEP & CCEP & CCEP \\
\hline$F L_{i, t-1}$ & $\begin{array}{l}0.081 \\
{[0.050]}\end{array}$ & $\begin{array}{l}0.096 \\
{[0.046]^{* *}}\end{array}$ & $\begin{array}{l}0.074 \\
{[0.054]}\end{array}$ & $\begin{array}{l}-0.204 \\
{[0.063]^{* * *}}\end{array}$ & $\begin{array}{l}-0.191 \\
{[0.063]^{\star * *}}\end{array}$ & $\begin{array}{l}-0.199 \\
{[0.070]^{* * *}}\end{array}$ \\
\hline$F L_{i, t-1}^{2}$ & $\begin{array}{l}-0.104 \\
{[0.047]^{* *}}\end{array}$ & $\begin{array}{l}-0.113 \\
{[0.046]^{* *}}\end{array}$ & $\begin{array}{l}-0.113 \\
{[0.052]^{* *}}\end{array}$ & $\begin{array}{l}-0.218 \\
{[0.065]^{* * *}}\end{array}$ & $\begin{array}{l}-0.226 \\
{[0.065]^{* * *}}\end{array}$ & $\begin{array}{l}-0.250 \\
{[0.071]^{* * *}}\end{array}$ \\
\hline$R E G_{-} F L_{i, t-1}-F L_{i, t-1}$ & $\begin{array}{l}0.059 \\
{[0.025]^{\star *}}\end{array}$ & $\begin{array}{l}0.058 \\
{[0.028]^{* *}}\end{array}$ & $\begin{array}{l}0.058 \\
{[0.027]^{* *}}\end{array}$ & $\begin{array}{l}-0.137 \\
{[0.033]^{* * *}}\end{array}$ & $\begin{array}{l}-0.113 \\
{[0.033]^{\star * * *}}\end{array}$ & $\begin{array}{l}-0.085 \\
{[0.038]^{* *}}\end{array}$ \\
\hline$B O P_{i t}$ & & $\begin{array}{l}0.016 \\
{[0.006]^{* *}}\end{array}$ & $\begin{array}{l}0.011 \\
{[0.006]^{*}}\end{array}$ & & $\begin{array}{l}0.007 \\
{[0.006]}\end{array}$ & $\begin{array}{l}0.006 \\
{[0.007]}\end{array}$ \\
\hline$B A N K_{i t}$ & & $\begin{array}{l}-0.024 \\
{[0.010]^{* *}}\end{array}$ & $\begin{array}{l}-0.020 \\
{[0.009]^{* *}}\end{array}$ & & $\begin{array}{l}-0.023 \\
{[0.007]^{* * *}}\end{array}$ & $\begin{array}{l}-0.021 \\
{[0.007]^{* * *}}\end{array}$ \\
\hline$R_{E C E S S I O N}$ & & $\begin{array}{l}-0.010 \\
{[0.010]}\end{array}$ & $\begin{array}{l}-0.009 \\
{[0.010]}\end{array}$ & & $\begin{array}{l}-0.002 \\
{[0.007]}\end{array}$ & $\begin{array}{l}-0.006 \\
{[0.007]}\end{array}$ \\
\hline$H_{I N F L}{ }_{i t}$ & & $\begin{array}{l}-0.003 \\
{[0.020]}\end{array}$ & $\begin{array}{l}-0.002 \\
{[0.020]}\end{array}$ & & $\begin{array}{l}-0.041 \\
{[0.011]^{* * *}}\end{array}$ & $\begin{array}{l}-0.044 \\
{[0.012]^{* * *}}\end{array}$ \\
\hline FIRSTYEAR $_{i t}$ & & & $\begin{array}{l}0.011 \\
{[0.006]^{*}}\end{array}$ & & & $\begin{array}{l}0.010 \\
{[0.006]^{*}}\end{array}$ \\
\hline$I M F_{i t}$ & & & $\begin{array}{l}0.012 \\
{[0.009]}\end{array}$ & & & $\begin{array}{l}0.014 \\
{[0.007]^{\star *}}\end{array}$ \\
\hline USINT $_{i t}$ & & & $\begin{array}{l}-0.003 \\
{[0.001]^{\text {** }}}\end{array}$ & & & $\begin{array}{l}-0.003 \\
{[0.001]^{* *}}\end{array}$ \\
\hline$L E F T_{i t}$ & & & $\begin{array}{l}0.002 \\
{[0.008]}\end{array}$ & & & $\begin{array}{l}-0.019 \\
{[0.010]^{*}}\end{array}$ \\
\hline$R_{I G H T}$ it & & & $\begin{array}{l}0.003 \\
{[0.008]}\end{array}$ & & & $\begin{array}{l}-0.001 \\
{[0.010]}\end{array}$ \\
\hline OPEN $_{i t}$ & & & $\begin{array}{l}0.000 \\
{[0.000]^{*}}\end{array}$ & & & $\begin{array}{l}0.001 \\
{[0.000]^{*}}\end{array}$ \\
\hline$D E M O_{i t}$ & & & $\begin{array}{l}-0.011 \\
{[0.013]}\end{array}$ & & & $\begin{array}{l}-0.044 \\
{[0.020]^{* *}}\end{array}$ \\
\hline Observations & 805 & 805 & 805 & 805 & 805 & 805 \\
\hline Number of country & 35 & 35 & 35 & 35 & 35.00 & 35 \\
\hline R-squared & 0.03 & 0.05 & 0.08 & 0.31 & 0.33 & 0.40 \\
\hline
\end{tabular}

Note: Panel-robust standard errors are reported for WG estimates, while nonrobust standard errors are reported for CCEP estimates. See Table 1 for further notes. 
B. Within estimates corresponding to Table 2

\begin{tabular}{|c|c|c|c|c|}
\hline Estimators & WG & WG & CCEP & CCEP \\
\hline$F L_{i, t-1}$ & $\begin{array}{l}0.074 \\
{[0.054]}\end{array}$ & $\begin{array}{l}0.092 \\
{[0.054]^{*}}\end{array}$ & $\begin{array}{l}-0.199 \\
{[0.070]^{* * *}}\end{array}$ & $\begin{array}{l}-0.392 \\
{[0.091]^{* * *}}\end{array}$ \\
\hline$\left(F L_{i, t-1}\right)^{2}$ & $\begin{array}{l}-0.113 \\
{[0.052]^{\star *}}\end{array}$ & $\begin{array}{l}-0.201 \\
{[0.069]^{* * *}}\end{array}$ & $\begin{array}{l}-0.250 \\
{[0.071]^{\star * *}}\end{array}$ & $\begin{array}{l}-0.235 \\
{[0.107]^{* *}}\end{array}$ \\
\hline$F L_{i, t-1} \times Y_{i, t-1}$ & & $\begin{array}{l}0.007 \\
{[0.003]^{* *}}\end{array}$ & & $\begin{array}{l}0.016 \\
{[0.008]^{*}}\end{array}$ \\
\hline$R E G_{-} F L_{i, t-1}-F L_{i, t-1}$ & $\begin{array}{l}0.058 \\
{[0.027]^{* *}}\end{array}$ & $\begin{array}{l}0.063 \\
{[0.025]^{* *}}\end{array}$ & $\begin{array}{l}-0.085 \\
{[0.038]^{* *}}\end{array}$ & $\begin{array}{l}0.062 \\
{[0.043]}\end{array}$ \\
\hline$B O P_{i t}$ & $\begin{array}{l}0.011 \\
{[0.006]^{*}}\end{array}$ & $\begin{array}{l}0.011 \\
{[0.006]^{*}}\end{array}$ & $\begin{array}{l}0.006 \\
{[0.007]}\end{array}$ & $\begin{array}{l}-0.005 \\
{[0.007]}\end{array}$ \\
\hline$B A N K_{i t}$ & $\begin{array}{l}-0.02 \\
{[0.009]^{* *}}\end{array}$ & $\begin{array}{l}-0.022 \\
{[0.009]^{* *}}\end{array}$ & $\begin{array}{l}-0.021 \\
{[0.007]^{* * *}}\end{array}$ & $\begin{array}{l}-0.022 \\
{[0.008]^{* * *}}\end{array}$ \\
\hline$R E C E S S I O N_{i t}$ & $\begin{array}{l}-0.009 \\
{[0.010]}\end{array}$ & $\begin{array}{l}-0.008 \\
{[0.009]}\end{array}$ & $\begin{array}{l}-0.006 \\
{[0.007]}\end{array}$ & $\begin{array}{l}-0.012 \\
{[0.007]}\end{array}$ \\
\hline$H I N F L_{i t}$ & $\begin{array}{l}-0.002 \\
{[0.020]}\end{array}$ & $\begin{array}{l}-0.005 \\
{[0.020]}\end{array}$ & $\begin{array}{l}-0.044 \\
{[0.012]^{* * *}}\end{array}$ & $\begin{array}{l}-0.017 \\
{[0.015]}\end{array}$ \\
\hline$F_{I R S T Y E A R}$ & $\begin{array}{l}0.011 \\
{[0.006]^{*}}\end{array}$ & $\begin{array}{l}0.011 \\
{[0.006]^{*}}\end{array}$ & $\begin{array}{l}0.010 \\
{[0.006]^{*}}\end{array}$ & $\begin{array}{l}0.008 \\
{[0.006]}\end{array}$ \\
\hline$I M F_{i t}$ & $\begin{array}{l}0.012 \\
{[0.009]}\end{array}$ & $\begin{array}{l}0.012 \\
{[0.009]}\end{array}$ & $\begin{array}{l}0.014 \\
{[0.007]^{* *}}\end{array}$ & $\begin{array}{l}0.012 \\
{[0.007]^{*}}\end{array}$ \\
\hline$U_{S I N T_{i t}}$ & $\begin{array}{l}-0.003 \\
{[0.001]^{* *}}\end{array}$ & $\begin{array}{l}-0.003 \\
{[0.001]^{* *}}\end{array}$ & $\begin{array}{l}-0.003 \\
{[0.001]^{* *}}\end{array}$ & $\begin{array}{l}-0.001 \\
{[0.002]}\end{array}$ \\
\hline$L E F T_{i t}$ & $\begin{array}{l}0.002 \\
{[0.008]}\end{array}$ & $\begin{array}{l}0 \\
{[0.008]}\end{array}$ & $\begin{array}{l}-0.019 \\
{[0.010]^{*}}\end{array}$ & $\begin{array}{l}-0.019 \\
{[0.011]^{*}}\end{array}$ \\
\hline$R I G H T_{i t}$ & $\begin{array}{l}0.003 \\
{[0.008]}\end{array}$ & $\begin{array}{l}0.003 \\
{[0.009]}\end{array}$ & $\begin{array}{l}-0.001 \\
{[0.010]}\end{array}$ & $\begin{array}{l}-0.018 \\
{[0.011]^{*}}\end{array}$ \\
\hline$O P E N_{i t}$ & $\begin{array}{l}0 \\
{[0.000]^{*}}\end{array}$ & $\begin{array}{l}0 \\
{[0.000]^{*}}\end{array}$ & $\begin{array}{l}0.001 \\
{[0.000]^{*}}\end{array}$ & $\begin{array}{l}0.001 \\
{[0.000]^{*}}\end{array}$ \\
\hline$D E M O_{i t}$ & $\begin{array}{l}-0.011 \\
{[0.013]}\end{array}$ & $\begin{array}{l}-0.01 \\
{[0.013]}\end{array}$ & $\begin{array}{l}-0.044 \\
{[0.020]^{* *}}\end{array}$ & $\begin{array}{l}-0.089 \\
{[0.024]^{* * *}}\end{array}$ \\
\hline Observations & 805 & $\begin{array}{l}805 \\
35\end{array}$ & $\begin{array}{l}805 \\
35\end{array}$ & $\begin{array}{l}805 \\
35\end{array}$ \\
\hline $\begin{array}{l}\text { Number of country } \\
\text { R-squared }\end{array}$ & $\begin{array}{l}35 \\
0.08\end{array}$ & 0.09 & 0.40 & 0.55 \\
\hline
\end{tabular}

Note: Panel-robust standard errors are reported for WG estimates, while nonrobust standard errors are reported for CCEP estimates. See Table 1 for further notes. 


\section{Within estimates corresponding to Table 3}

\begin{tabular}{|c|c|c|}
\hline Estimators & WG & CCEP \\
\hline $\begin{array}{ll}F L_{i, t-1} \\
\end{array}$ & $\begin{array}{l}-0.009 \\
{[0.062]}\end{array}$ & $\begin{array}{l}-0.045 \\
{[0.143]}\end{array}$ \\
\hline$\left(F L_{i, t-1}\right)^{2}$ & $\begin{array}{l}-0.011 \\
{[0.070]}\end{array}$ & $\begin{array}{l}-0.344 \\
{[0.142]^{* *}}\end{array}$ \\
\hline$R E G_{-} F L_{i, t-1}-F L_{i, t-1}$ & $\begin{array}{l}0.025 \\
{[0.029]}\end{array}$ & $\begin{array}{l}0.054 \\
{[0.045]}\end{array}$ \\
\hline$\left(R E G-F L_{i, t-1}-F L_{i, t-1}\right) \times F L_{i, t-1}$ & $\begin{array}{l}0.330 \\
{[0.084]^{* * *}}\end{array}$ & $\begin{array}{l}-0.098 \\
{[0.152]}\end{array}$ \\
\hline$B_{i t}$ & $\begin{array}{l}0.020 \\
{[0.010]^{*}}\end{array}$ & $\begin{array}{l}0.004 \\
{[0.011]}\end{array}$ \\
\hline$B O{ }_{i t} \times F L_{i, t-1}$ & $\begin{array}{l}-0.029 \\
{[0.021]}\end{array}$ & $\begin{array}{l}-0.029 \\
{[0.022]}\end{array}$ \\
\hline$B A N K \quad$ it & $\begin{array}{l}-0.023 \\
{[0.017]}\end{array}$ & $\begin{array}{l}-0.010 \\
{[0.014]}\end{array}$ \\
\hline$B A N K \quad$ it $\times F L_{i, t-1}$ & $\begin{array}{l}0.004 \\
{[0.026]}\end{array}$ & $\begin{array}{l}-0.035 \\
{[0.029]}\end{array}$ \\
\hline RECESSION it & $\begin{array}{l}-0.015 \\
{[0.016]}\end{array}$ & $\begin{array}{l}-0.015 \\
{[0.011]}\end{array}$ \\
\hline RECESSION $\quad{ }_{i t} \times F L_{i, t-1}$ & $\begin{array}{l}0.020 \\
{[0.022]}\end{array}$ & $\begin{array}{l}0.007 \\
{[0.022]}\end{array}$ \\
\hline HINFL it & $\begin{array}{l}0.030 \\
{[0.027]}\end{array}$ & $\begin{array}{l}0.007 \\
{[0.019]}\end{array}$ \\
\hline HINFL $\quad$ it $\times F L_{i, t-1}$ & $\begin{array}{l}-0.156 \\
{[0.059]^{* *}}\end{array}$ & $\begin{array}{l}-0.117 \\
{[0.058]^{* *}}\end{array}$ \\
\hline FIRSTYEAR it & $\begin{array}{l}0.028 \\
{[0.010]^{* *}}\end{array}$ & $\begin{array}{l}0.031 \\
{[0.009]^{* * *}}\end{array}$ \\
\hline FIRSTYEAR ${ }_{i t} \times F L_{i, t-1}$ & $\begin{array}{l}-0.049 \\
{[0.024]^{*}}\end{array}$ & $\begin{array}{l}-0.064 \\
{[0.019]^{* * *}}\end{array}$ \\
\hline IMF ${ }_{i t}$ & $\begin{array}{l}0.020 \\
{[0.011]^{*}}\end{array}$ & $\begin{array}{l}0.023 \\
{[0.010]^{* *}}\end{array}$ \\
\hline$I M F_{i t} \times F L_{i, t-1}$ & $\begin{array}{l}-0.050 \\
{[0.022]^{* *}}\end{array}$ & $\begin{array}{l}-0.069 \\
{[0.033]^{* *}}\end{array}$ \\
\hline USINT it & $\begin{array}{l}-0.003 \\
{[0.001]^{* *}}\end{array}$ & $\begin{array}{l}-0.001 \\
{[0.002]}\end{array}$ \\
\hline LEFT it & $\begin{array}{l}-0.025 \\
{[0.015]}\end{array}$ & $\begin{array}{l}-0.034 \\
{[0.016]^{* *}}\end{array}$ \\
\hline$L E F T_{i t} \times F L_{i, t-1}$ & $\begin{array}{l}0.068 \\
{[0.038]^{*}}\end{array}$ & $\begin{array}{l}0.024 \\
{[0.038]}\end{array}$ \\
\hline RIGHT it & $\begin{array}{l}0.006 \\
{[0.011]}\end{array}$ & $\begin{array}{l}-0.012 \\
{[0.015]}\end{array}$ \\
\hline$R I G H T \quad{ }_{i t} \times F L_{i, t-1}$ & $\begin{array}{l}0.020 \\
{[0.034]}\end{array}$ & $\begin{array}{l}-0.030 \\
{[0.042]}\end{array}$ \\
\hline OPEN it & $\begin{array}{l}0.001 \\
{[0.000]^{* *}}\end{array}$ & $\begin{array}{l}0.002 \\
{[0.001]^{\star * *}}\end{array}$ \\
\hline OPEN ${ }_{i t} \times F L_{i, t-1}$ & $\begin{array}{l}-0.001 \\
{[0.000]^{* *}}\end{array}$ & $\begin{array}{l}-0.002 \\
{[0.001]^{* *}}\end{array}$ \\
\hline$D E M O$ it & $\begin{array}{l}-0.030 \\
{[0.026]}\end{array}$ & $\begin{array}{l}-0.115 \\
{[0.028]^{\star * *}}\end{array}$ \\
\hline$D E M O{ }_{i t} \times F L_{i, t-1}$ & $\begin{array}{l}0.002 \\
{[0.002]}\end{array}$ & $\begin{array}{l}0.007 \\
{[0.004]^{*}}\end{array}$ \\
\hline Observations & 805 & 805 \\
\hline Number of country & 35 & 35 \\
\hline R-squared & 0.14 & 0.57 \\
\hline
\end{tabular}

Note: Panel-robust standard errors are reported for WG estimates, while nonrobust standard errors are reported for CCEP estimates. See Table 1 for further notes. 
Appendix Table 6. Augmented dataset with Chinn-Ito measure (2005): IMF dropped

A. Within estimates corresponding to Table 1B

\begin{tabular}{|c|c|c|c|c|c|c|}
\hline Estimators & WG & WG & WG & CCEP & CCEP & CCEP \\
\hline$F L_{i, t-1}$ & $\begin{array}{l}-0.168 \\
{[0.044]^{\star * *}}\end{array}$ & $\begin{array}{l}-0.170 \\
{[0.044]^{\star * *}}\end{array}$ & $\begin{array}{l}-0.174 \\
{[0.045]^{\star * *}}\end{array}$ & $\begin{array}{l}-0.204 \\
{[0.069]^{* * *}}\end{array}$ & $\begin{array}{l}-0.214 \\
{[0.068]^{* * *}}\end{array}$ & $\begin{array}{l}-0.261 \\
{[0.084]^{\star * *}}\end{array}$ \\
\hline$F L_{i, t-1}{ }^{2}$ & $\begin{array}{l}0.052 \\
{[0.037]}\end{array}$ & $\begin{array}{l}0.053 \\
{[0.037]}\end{array}$ & $\begin{array}{l}0.056 \\
{[0.038]}\end{array}$ & $\begin{array}{l}0.087 \\
{[0.049]^{*}}\end{array}$ & $\begin{array}{l}0.092 \\
{[0.049]^{*}}\end{array}$ & $\begin{array}{l}0.119 \\
{[0.059]^{* *}}\end{array}$ \\
\hline$R E G_{-} F L_{i, t-1}-F L_{i, t-1}$ & $\begin{array}{l}-0.016 \\
{[0.027]}\end{array}$ & $\begin{array}{l}-0.018 \\
{[0.027]}\end{array}$ & $\begin{array}{l}0.002 \\
{[0.028]}\end{array}$ & $\begin{array}{l}0.048 \\
{[0.036]}\end{array}$ & $\begin{array}{l}0.044 \\
{[0.037]}\end{array}$ & $\begin{array}{l}0.044 \\
{[0.036]}\end{array}$ \\
\hline$B O P_{i t}$ & & $\begin{array}{l}0.002 \\
{[0.007]}\end{array}$ & $\begin{array}{l}0.001 \\
{[0.007]}\end{array}$ & & $\begin{array}{l}-0.005 \\
{[0.007]}\end{array}$ & $\begin{array}{l}-0.006 \\
{[0.008]}\end{array}$ \\
\hline$B A N K_{i t}$ & & $\begin{array}{l}-0.010 \\
{[0.009]}\end{array}$ & $\begin{array}{l}-0.010 \\
{[0.009]}\end{array}$ & & $\begin{array}{l}-0.008 \\
{[0.010]}\end{array}$ & $\begin{array}{l}-0.009 \\
{[0.011]}\end{array}$ \\
\hline RECESSION $_{i t}$ & & $\begin{array}{l}-0.001 \\
{[0.007]}\end{array}$ & $\begin{array}{l}0.000 \\
{[0.007]}\end{array}$ & & $\begin{array}{l}0.001 \\
{[0.008]}\end{array}$ & $\begin{array}{l}0.001 \\
{[0.009]}\end{array}$ \\
\hline$H_{I N F L}{ }_{i t}$ & & $\begin{array}{l}-0.018 \\
{[0.012]}\end{array}$ & $\begin{array}{l}-0.017 \\
{[0.013]}\end{array}$ & & $\begin{array}{l}-0.009 \\
{[0.017]}\end{array}$ & $\begin{array}{l}-0.009 \\
{[0.017]}\end{array}$ \\
\hline FIRSTYEAR $_{i t}$ & & & $\begin{array}{l}0.000 \\
{[0.007]}\end{array}$ & & & $\begin{array}{l}0.001 \\
{[0.006]}\end{array}$ \\
\hline USINT $_{i t}$ & & & $\begin{array}{l}-0.005 \\
{[0.001]^{* * *}}\end{array}$ & & & $\begin{array}{l}-0.002 \\
{[0.002]}\end{array}$ \\
\hline$L E F T_{i t}$ & & & $\begin{array}{l}-0.004 \\
{[0.010]}\end{array}$ & & & $\begin{array}{l}-0.008 \\
{[0.009]}\end{array}$ \\
\hline$R_{I G H T}{ }_{i t}$ & & & $\begin{array}{l}0.000 \\
{[0.010]}\end{array}$ & & & $\begin{array}{l}0.000 \\
{[0.011]}\end{array}$ \\
\hline$O{ }_{i t}$ & & & $\begin{array}{l}0.000 \\
{[0.000]^{*}}\end{array}$ & & & $\begin{array}{l}0.000 \\
{[0.000]}\end{array}$ \\
\hline$D E M O{ }_{i t}$ & & & $\begin{array}{l}-0.002 \\
{[0.016]}\end{array}$ & & & $\begin{array}{l}0.012 \\
{[0.022]}\end{array}$ \\
\hline Observations & 1263 & 1262 & 1213 & 1263 & 1262 & 1213 \\
\hline Number of country & 55 & 55 & 53 & 55 & 55 & 53 \\
\hline R-squared & 0.04 & 0.04 & 0.07 & 0.22 & 0.22 & 0.25 \\
\hline
\end{tabular}

Note: See Table 4A for notes. 
B. Within estimates corresponding to Table 2

\begin{tabular}{|c|c|c|c|c|}
\hline Estimators & WG & WG & CCEP & CCEP \\
\hline$F L_{i, t-1}$ & $\begin{array}{l}-0.174 \\
{[0.045]^{* * *}}\end{array}$ & $\begin{array}{l}-0.169 \\
{[0.045]^{* * *}}\end{array}$ & $\begin{array}{l}-0.261 \\
{[0.084]^{* * *}}\end{array}$ & $\begin{array}{l}-0.343 \\
{[0.118]^{* * *}}\end{array}$ \\
\hline$\left(F L_{i, t-1}\right)^{2}$ & $\begin{array}{l}0.056 \\
{[0.038]}\end{array}$ & $\begin{array}{l}0.006 \\
{[0.044]}\end{array}$ & $\begin{array}{l}0.119 \\
{[0.059]^{* *}}\end{array}$ & $\begin{array}{l}0.079 \\
{[0.081]}\end{array}$ \\
\hline$F L_{i, t-1} \times Y_{i, t-1}$ & & $\begin{array}{l}0.004 \\
{[0.002]^{* *}}\end{array}$ & & $\begin{array}{l}0.004 \\
{[0.004]}\end{array}$ \\
\hline$R E G_{-} F L_{i, t-1}-F L_{i, t-1}$ & $\begin{array}{l}0.002 \\
{[0.028]}\end{array}$ & $\begin{array}{l}0.007 \\
{[0.028]}\end{array}$ & $\begin{array}{l}0.044 \\
{[0.036]}\end{array}$ & $\begin{array}{l}0.012 \\
{[0.048]}\end{array}$ \\
\hline$B O P_{i t}$ & $\begin{array}{l}0.001 \\
{[0.007]}\end{array}$ & $\begin{array}{l}0.001 \\
{[0.007]}\end{array}$ & $\begin{array}{l}-0.006 \\
{[0.008]}\end{array}$ & $\begin{array}{l}-0.011 \\
{[0.009]}\end{array}$ \\
\hline$B A N K_{i t}$ & $\begin{array}{l}-0.010 \\
{[0.009]}\end{array}$ & $\begin{array}{l}-0.010 \\
{[0.009]}\end{array}$ & $\begin{array}{l}-0.009 \\
{[0.011]}\end{array}$ & $\begin{array}{l}0.000 \\
{[0.013]}\end{array}$ \\
\hline$R E C E S S I O N_{i t}$ & $\begin{array}{l}0.000 \\
{[0.007]}\end{array}$ & $\begin{array}{l}0.001 \\
{[0.007]}\end{array}$ & $\begin{array}{l}0.001 \\
{[0.009]}\end{array}$ & $\begin{array}{l}0.002 \\
{[0.009]}\end{array}$ \\
\hline$H I N F L_{i t}$ & $\begin{array}{l}-0.017 \\
{[0.013]}\end{array}$ & $\begin{array}{l}-0.020 \\
{[0.013]}\end{array}$ & $\begin{array}{l}-0.009 \\
{[0.017]}\end{array}$ & $\begin{array}{l}0.000 \\
{[0.016]}\end{array}$ \\
\hline$F_{I R S T Y E A R}$ & $\begin{array}{l}0.000 \\
{[0.007]}\end{array}$ & $\begin{array}{l}0.000 \\
{[0.007]}\end{array}$ & $\begin{array}{l}0.001 \\
{[0.006]}\end{array}$ & $\begin{array}{l}0.000 \\
{[0.006]}\end{array}$ \\
\hline $\operatorname{USINT}_{i t}$ & $\begin{array}{l}-0.005 \\
{[0.001]^{* * *}}\end{array}$ & $\begin{array}{l}-0.004 \\
{[0.001]^{* * *}}\end{array}$ & $\begin{array}{l}-0.002 \\
{[0.002]}\end{array}$ & $\begin{array}{l}-0.001 \\
{[0.002]}\end{array}$ \\
\hline$L E F T_{i t}$ & $\begin{array}{l}-0.004 \\
{[0.010]}\end{array}$ & $\begin{array}{l}-0.006 \\
{[0.010]}\end{array}$ & $\begin{array}{l}-0.008 \\
{[0.009]}\end{array}$ & $\begin{array}{l}-0.012 \\
{[0.010]}\end{array}$ \\
\hline$R I G H T_{i t}$ & $\begin{array}{l}0.000 \\
{[0.010]}\end{array}$ & $\begin{array}{l}-0.001 \\
{[0.010]}\end{array}$ & $\begin{array}{l}0.000 \\
{[0.011]}\end{array}$ & $\begin{array}{l}-0.004 \\
{[0.015]}\end{array}$ \\
\hline$O P E N_{i t}$ & $\begin{array}{l}0.000 \\
{[0.000]^{*}}\end{array}$ & $\begin{array}{l}0.000 \\
{[0.000]^{*}}\end{array}$ & $\begin{array}{l}0.000 \\
{[0.000]}\end{array}$ & $\begin{array}{l}0.000 \\
{[0.000]}\end{array}$ \\
\hline$D E M O_{i t}$ & $\begin{array}{l}-0.002 \\
{[0.016]}\end{array}$ & $\begin{array}{l}-0.002 \\
{[0.016]}\end{array}$ & $\begin{array}{l}0.012 \\
{[0.022]}\end{array}$ & $\begin{array}{l}0.019 \\
{[0.028]}\end{array}$ \\
\hline Observations & 1213 & 1213 & 1213 & 1213 \\
\hline Number of country & 53 & 53 & 53 & 53 \\
\hline R-squared & 0.07 & 0.07 & 0.25 & 0.31 \\
\hline
\end{tabular}

Note: See Table 4A for notes. 


\begin{tabular}{|c|c|c|}
\hline Estimators & WG & CCEP \\
\hline$F L_{i, t-1}$ & $\begin{array}{l}-0.303 \\
{[0.089]^{* * *}}\end{array}$ & $\begin{array}{l}-0.599 \\
{[0.232]^{* *}}\end{array}$ \\
\hline$\left(F L_{i, t-1}\right)^{2}$ & $\begin{array}{l}0.190 \\
{[0.081]^{* *}}\end{array}$ & $\begin{array}{l}0.355 \\
{[0.208]^{*}}\end{array}$ \\
\hline$R E G_{-} F L_{i, t-1}-F L_{i, t-1}$ & $\begin{array}{l}-0.024 \\
{[0.029]}\end{array}$ & $\begin{array}{l}-0.040 \\
{[0.053]}\end{array}$ \\
\hline$\left(R E G_{-} F L_{i, t-1}-F L_{i, t-1}\right) \times F L_{i, t-1}$ & $\begin{array}{l}0.216 \\
{[0.096]^{* *}}\end{array}$ & $\begin{array}{l}0.360 \\
{[0.224]}\end{array}$ \\
\hline$B O P_{i t}$ & $\begin{array}{l}-0.010 \\
{[0.011]}\end{array}$ & $\begin{array}{l}-0.010 \\
{[0.015]}\end{array}$ \\
\hline$B O P_{i t} \times F L_{i, t-1}$ & $\begin{array}{l}0.027 \\
{[0.020]}\end{array}$ & $\begin{array}{l}0.000 \\
{[0.025]}\end{array}$ \\
\hline$B A N K_{i t}$ & $\begin{array}{l}-0.008 \\
{[0.014]}\end{array}$ & $\begin{array}{l}0.002 \\
{[0.023]}\end{array}$ \\
\hline$B A N K_{i t} \times F L_{i, t-1}$ & $\begin{array}{l}-0.003 \\
{[0.025]}\end{array}$ & $\begin{array}{l}-0.009 \\
{[0.035]}\end{array}$ \\
\hline RECESSION $_{i t}$ & $\begin{array}{l}0.006 \\
{[0.010]}\end{array}$ & $\begin{array}{l}0.009 \\
{[0.011]}\end{array}$ \\
\hline RECESSION $_{i t} \times F L_{i, t-1}$ & $\begin{array}{l}-0.017 \\
{[0.020]}\end{array}$ & $\begin{array}{l}-0.023 \\
{[0.022]}\end{array}$ \\
\hline$H_{I N F L}{ }_{i t}$ & $\begin{array}{l}0.027 \\
{[0.017]}\end{array}$ & $\begin{array}{l}0.022 \\
{[0.031]}\end{array}$ \\
\hline$H I N F L_{i t} \times F L_{i, t-1}$ & $\begin{array}{l}-0.201 \\
{[0.049]^{* * *}}\end{array}$ & $\begin{array}{l}-0.103 \\
{[0.143]}\end{array}$ \\
\hline FIRSTYEAR it & $\begin{array}{l}-0.005 \\
{[0.011]}\end{array}$ & $\begin{array}{l}-0.005 \\
{[0.009]}\end{array}$ \\
\hline FIRSTYEAR $\quad{ }_{i t} \times F L_{i, t-1}$ & $\begin{array}{l}0.010 \\
{[0.020]}\end{array}$ & $\begin{array}{l}0.010 \\
{[0.018]}\end{array}$ \\
\hline USINT it & $\begin{array}{l}-0.005 \\
{[0.001]^{* * *}}\end{array}$ & $\begin{array}{l}-0.002 \\
{[0.002]}\end{array}$ \\
\hline$L E F T_{i t}$ & $\begin{array}{l}-0.017 \\
{[0.015]}\end{array}$ & $\begin{array}{l}-0.034 \\
{[0.025]}\end{array}$ \\
\hline$L E F T_{i t} \times F L_{i, t-1}$ & $\begin{array}{l}0.022 \\
{[0.030]}\end{array}$ & $\begin{array}{l}0.048 \\
{[0.049]}\end{array}$ \\
\hline$R_{I G H T}{ }_{i t}$ & $\begin{array}{l}0.009 \\
{[0.014]}\end{array}$ & $\begin{array}{l}-0.004 \\
{[0.025]}\end{array}$ \\
\hline$R I G H T_{i t} \times F L_{i, t-1}$ & $\begin{array}{l}-0.019 \\
{[0.030]}\end{array}$ & $\begin{array}{l}0.006 \\
{[0.043]}\end{array}$ \\
\hline$O P E N_{i t}$ & $\begin{array}{l}0.001 \\
{[0.000]^{* *}}\end{array}$ & $\begin{array}{l}0.000 \\
{[0.000]}\end{array}$ \\
\hline$O P E N_{i t} \times F L_{i, t-1}$ & $\begin{array}{l}0.000 \\
{[0.000]}\end{array}$ & $\begin{array}{l}0.000 \\
{[0.000]}\end{array}$ \\
\hline$D E M O_{i t}$ & $\begin{array}{l}-0.002 \\
{[0.019]}\end{array}$ & $\begin{array}{l}0.020 \\
{[0.033]}\end{array}$ \\
\hline$D E M O{ }_{i t} \times F L_{i, t-1}$ & $\begin{array}{l}0.002 \\
{[0.002]}\end{array}$ & $\begin{array}{l}0.002 \\
{[0.005]}\end{array}$ \\
\hline Observations & 1213 & 1213 \\
\hline Number of country & 53 & 53 \\
\hline R-squared & 0.09 & 0.33 \\
\hline
\end{tabular}

Note: See Table 4A for notes. 